\title{
قيمة الصورة الأدبية قديمًا وحديثًا
}

\author{
د. حصة بنت سعود بن عبدالله الهزاني \\ كلية العلوم والار اسات الإنسانية \\ بحوطة بني تميم جامعة سطام بن عبد العزيز
}




\section{مقدمة}

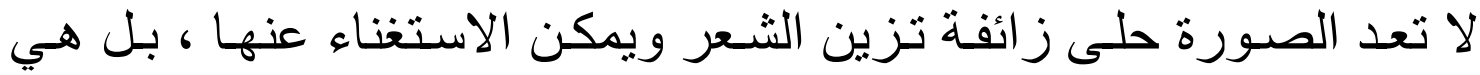

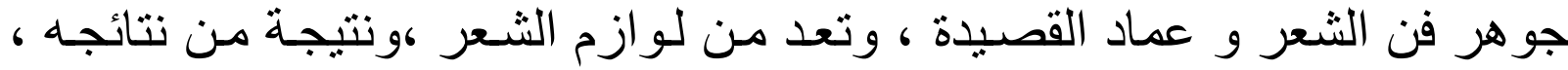

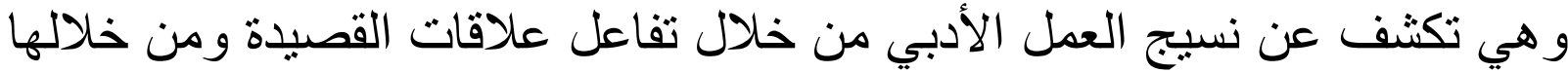

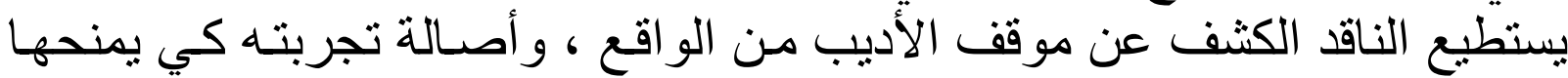

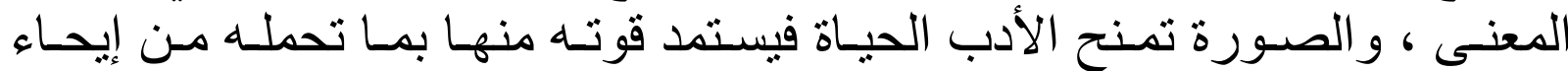

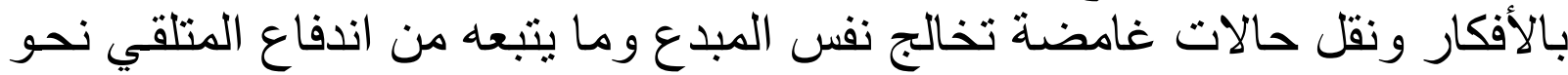

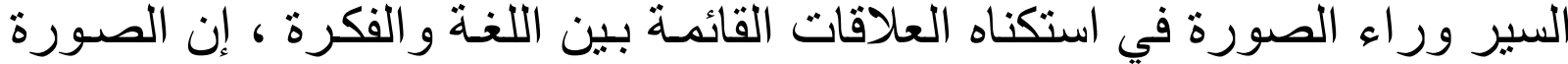

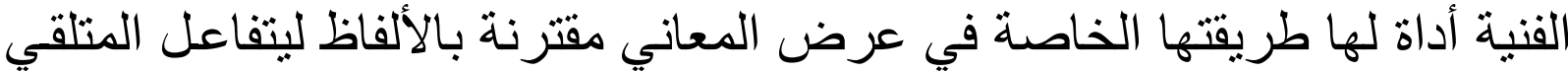

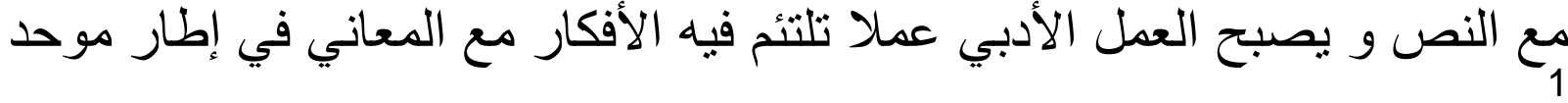

وهذا البحث سيتناول الصورة في ثلاثة مباحث، المبحث الأول عن ( مفهوم التهو

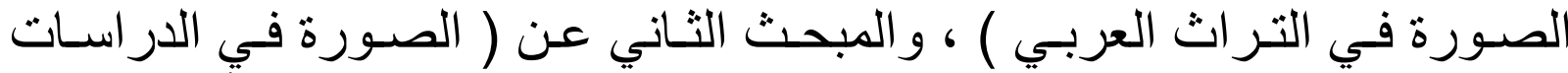

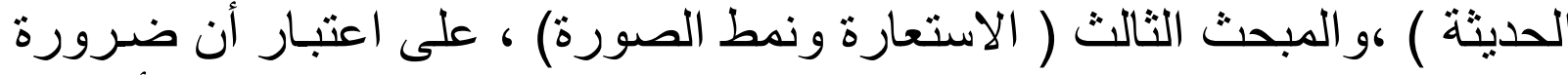

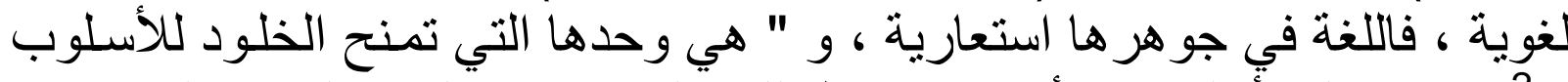

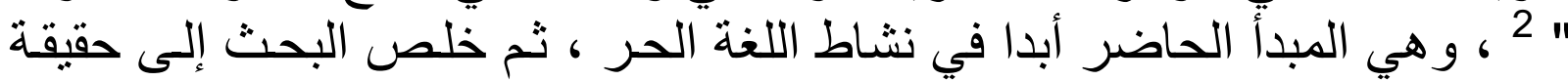

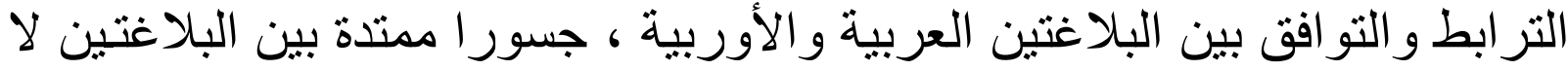

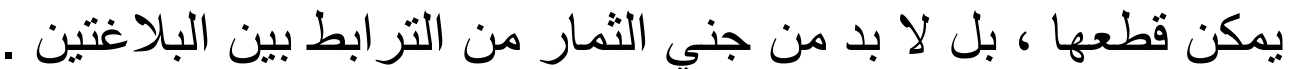

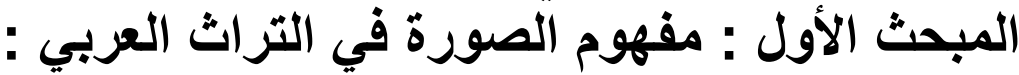

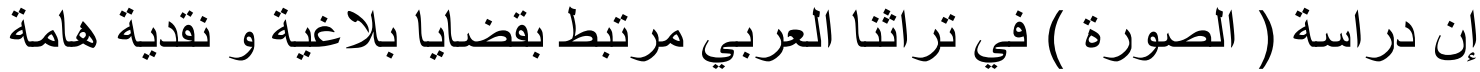

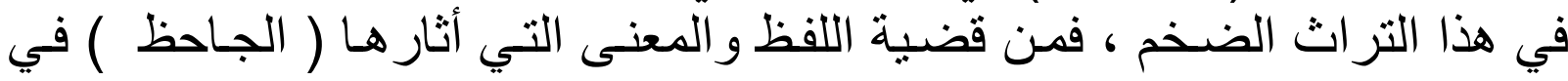

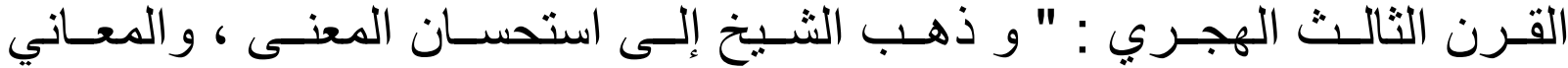

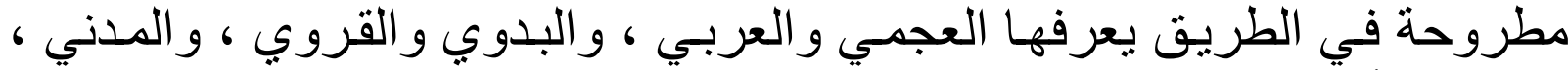

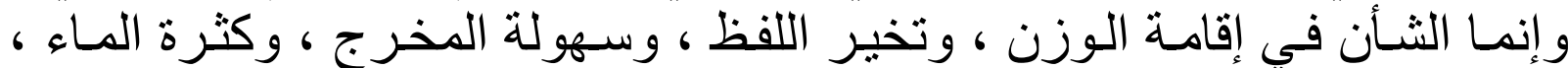

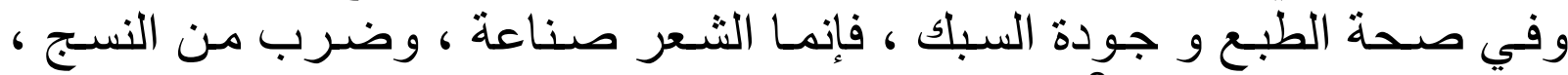

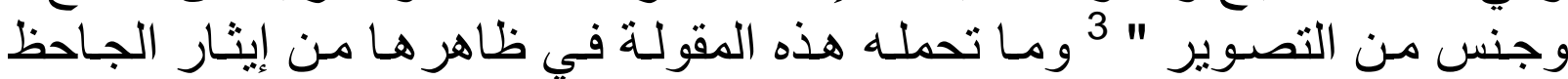

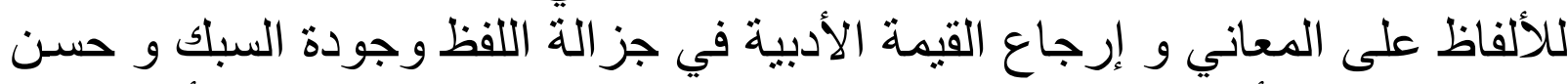

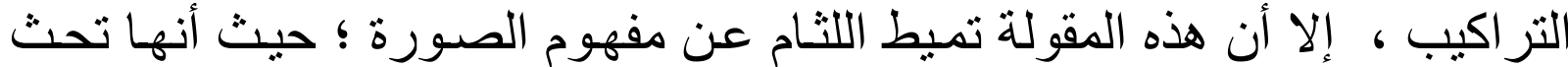

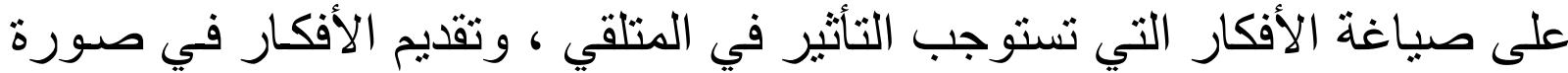

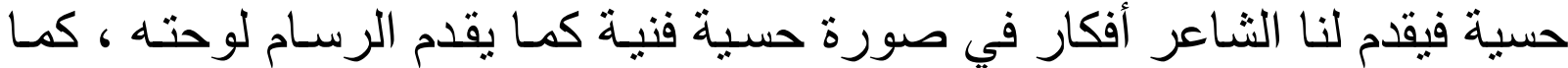

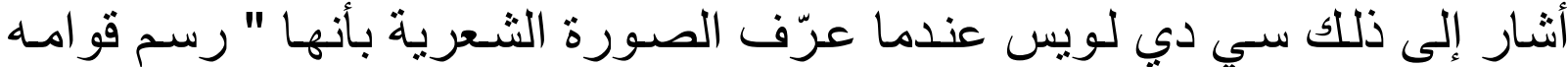

" : انظر : الصورة الفنبة في التراث النقدي و البلاغي ، جابر عصفور، دار الكتاب الدصري،ط 173 ، 1424هـ ،ص:313 .

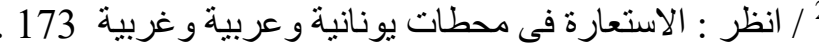
3 : الحيوان ، لأبي عثمان بن عمرو بن بحر الجاحظ ، دار الكتب العلمية ، بيروت ، ط3 ، 2011 ، ج3 ص : 67. 


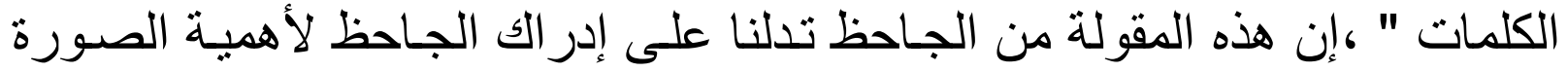

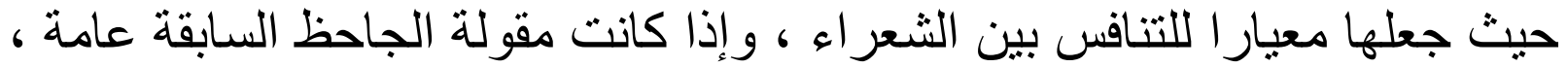

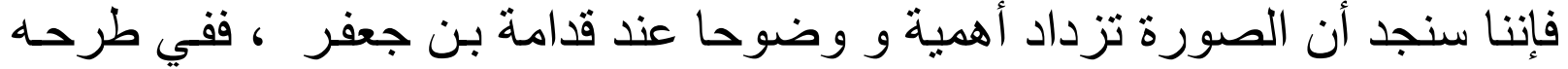

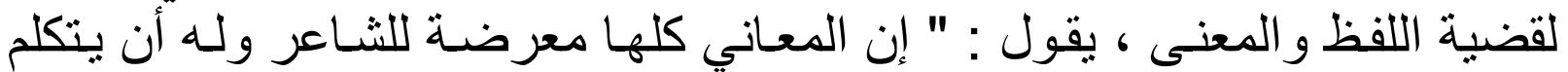

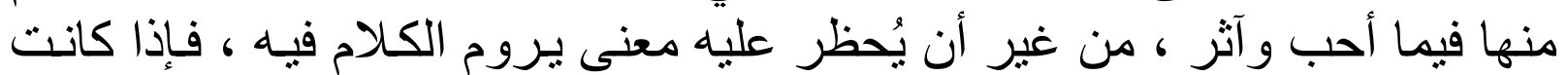

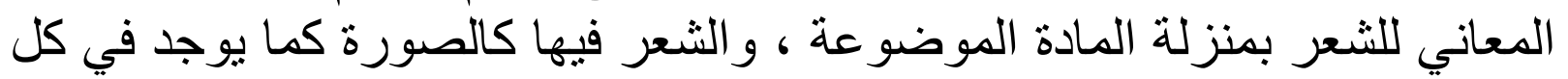

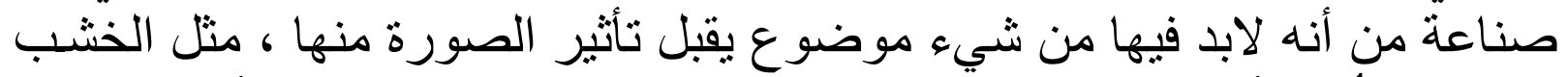

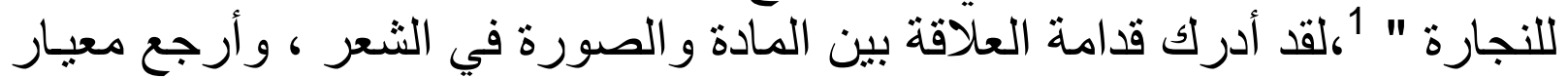

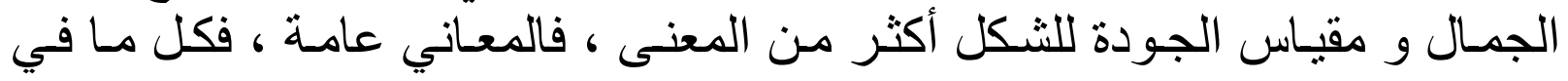

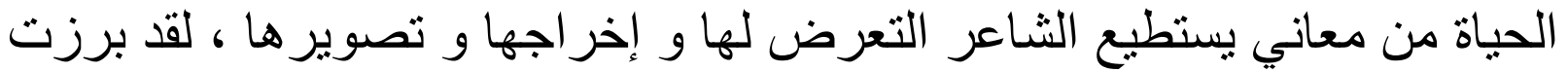

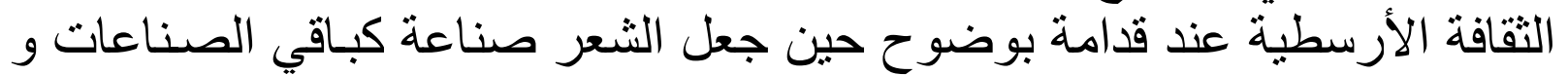

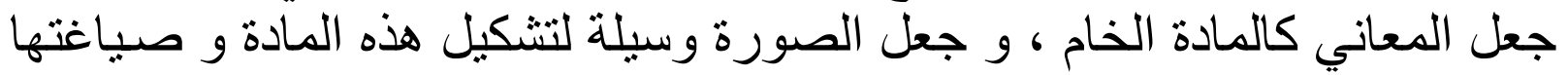

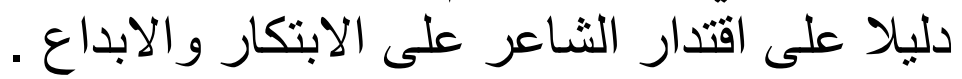
وفي القرن الخامس كان عبدالقاهر الجرجاني قد فئسل في الإنس القضية تفصيلا

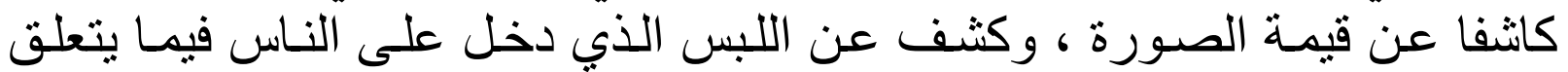

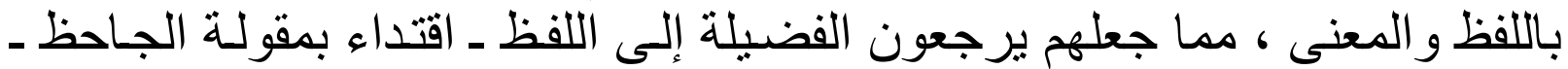

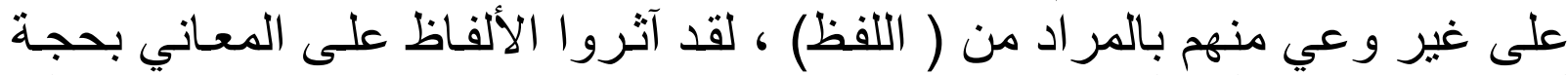

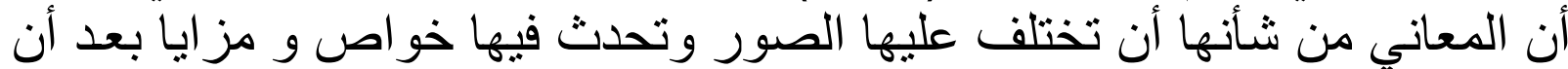

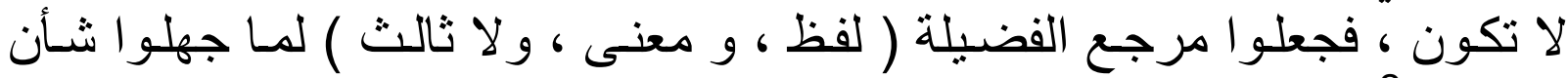
الصورة 2.

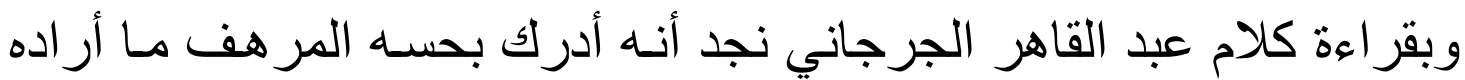

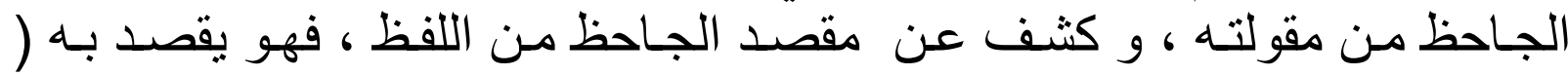

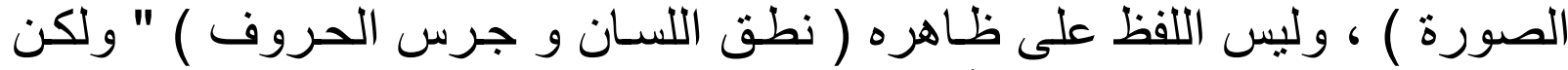

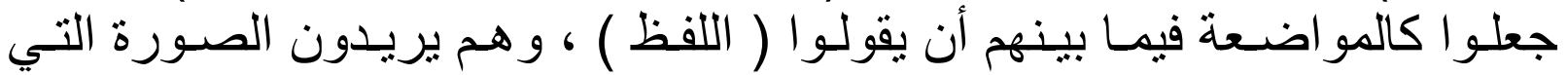

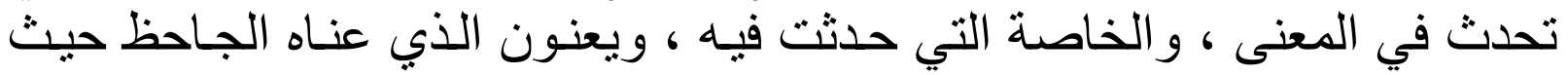

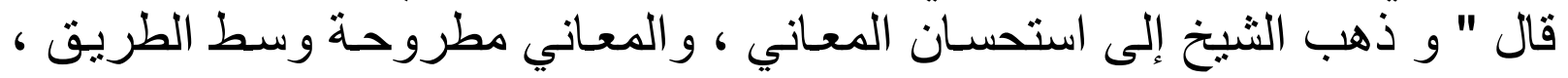

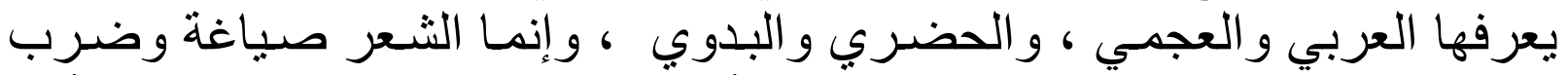

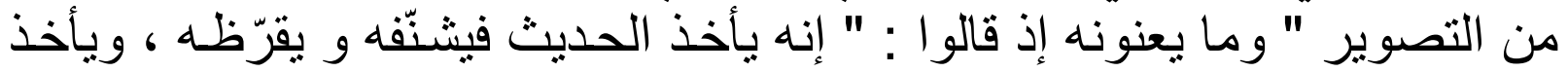

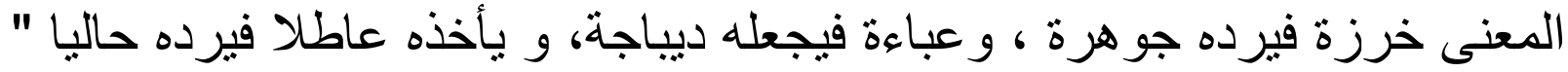

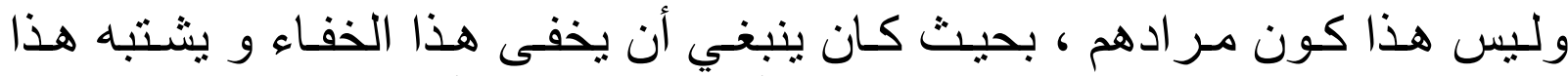

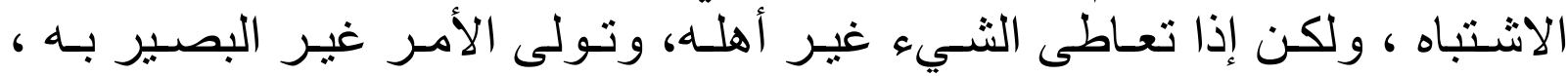


أعضل الداءو اشتد البلاء " 1،لقد نظر الجرجـاني إلى الصورة نظرة متكاملة لا

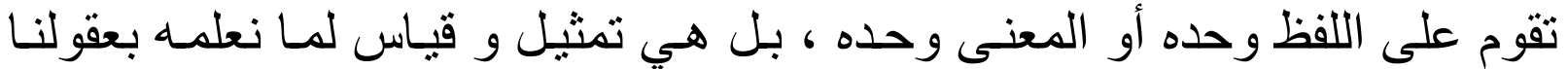

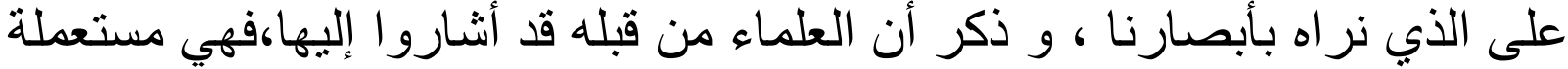

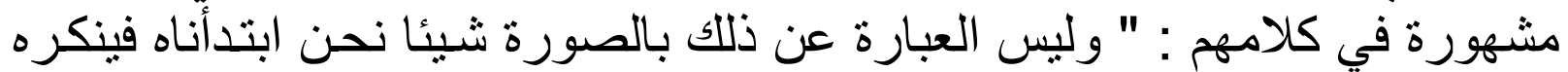

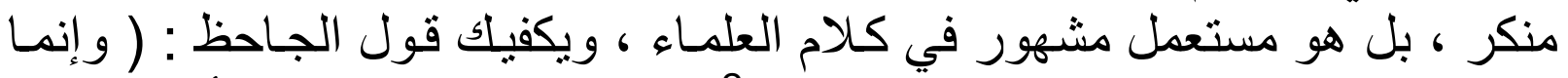

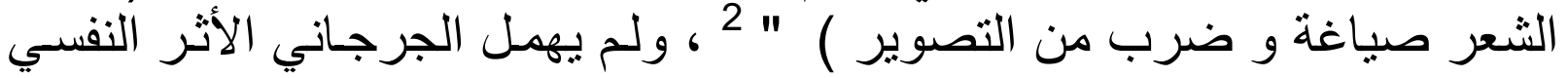

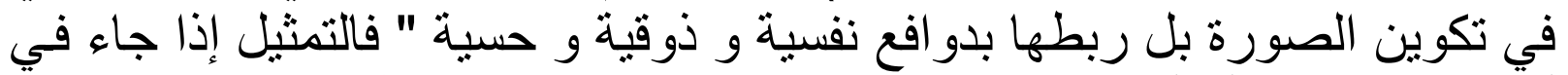

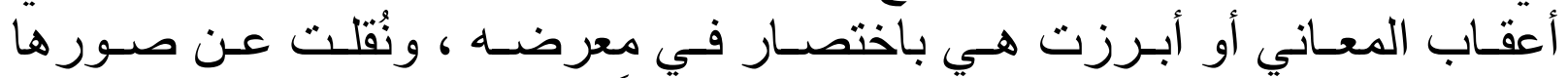

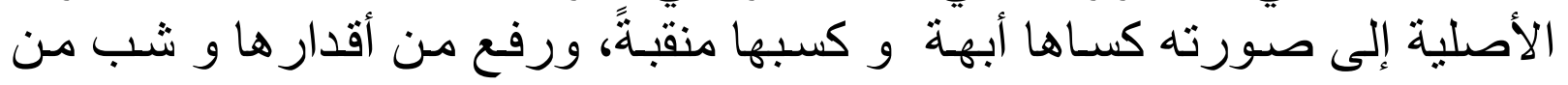

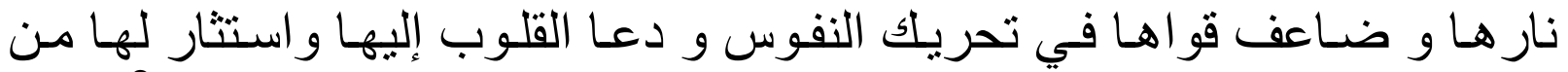

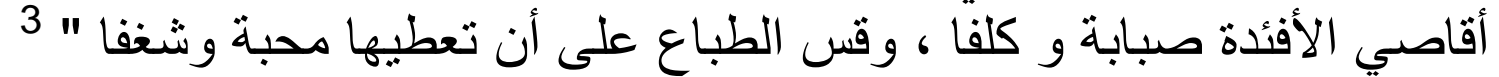

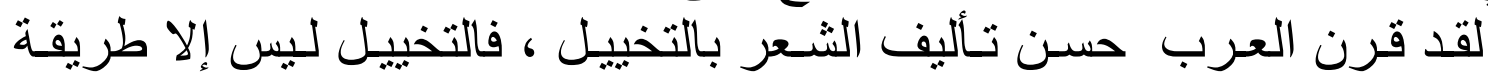

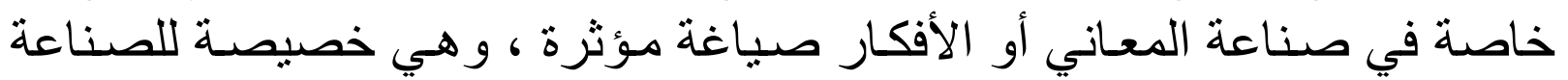

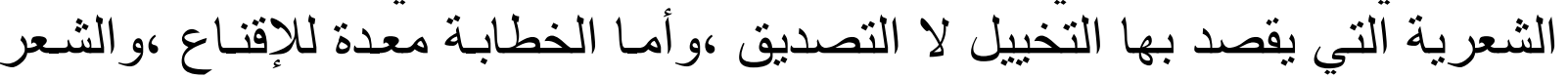

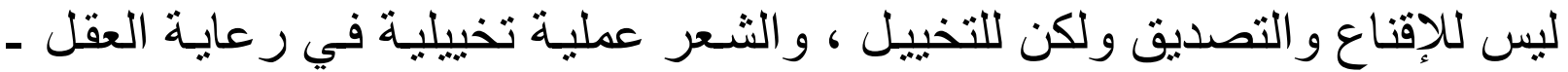

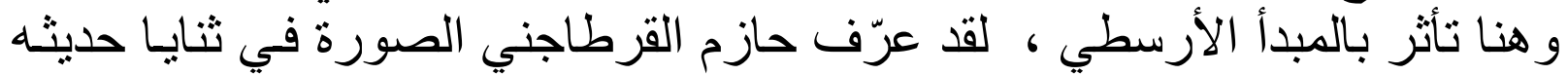

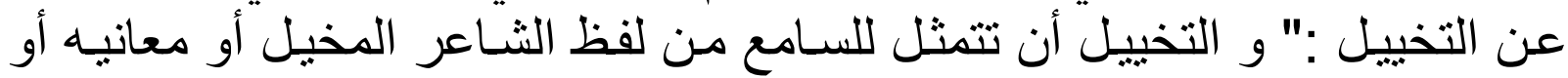

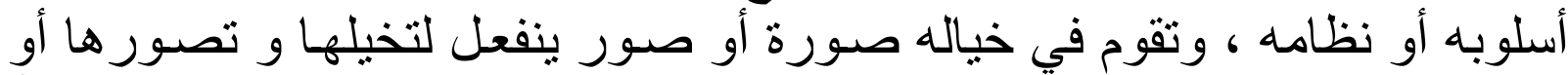

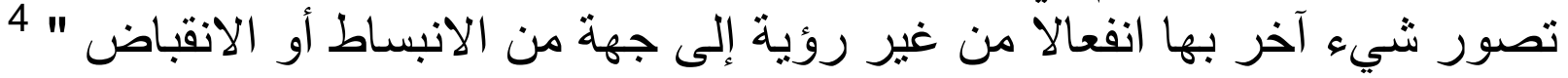

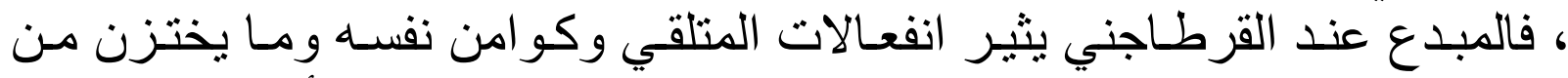

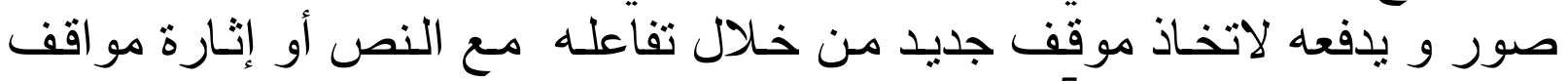

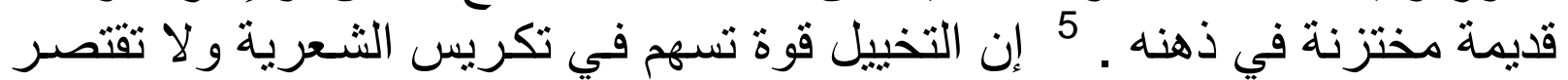

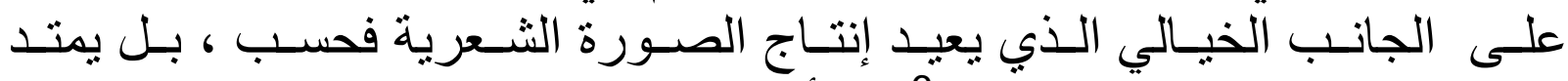

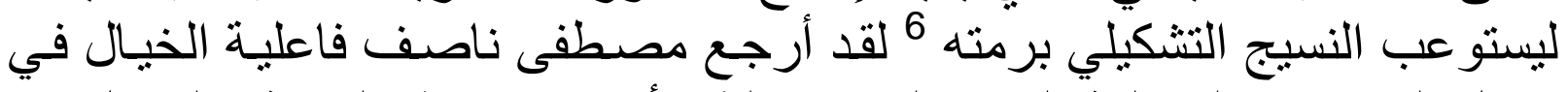

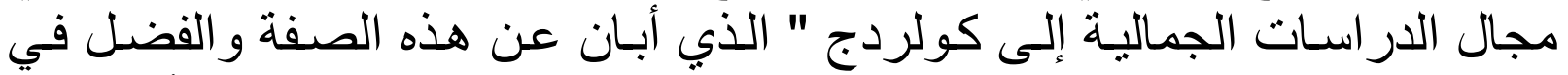

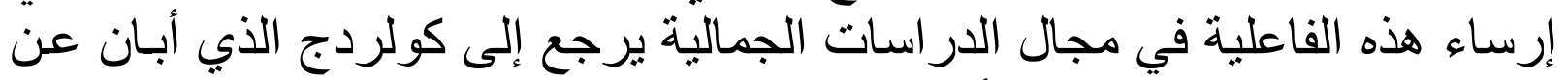

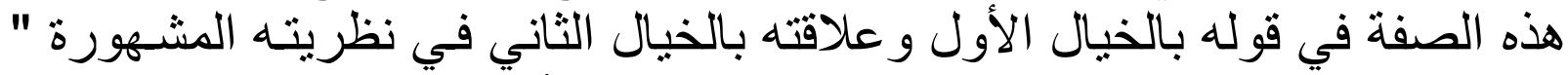

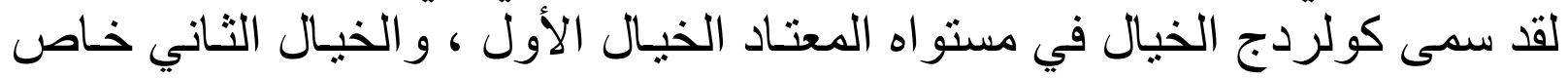

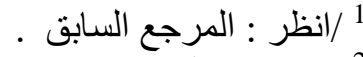

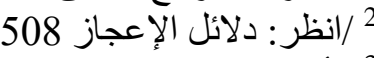

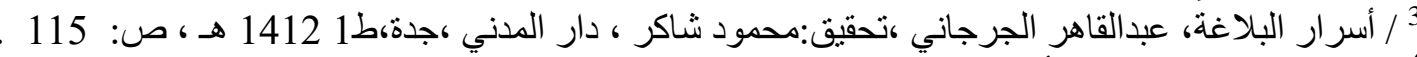

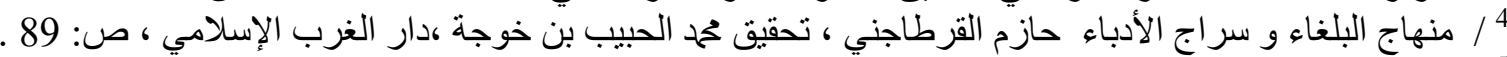

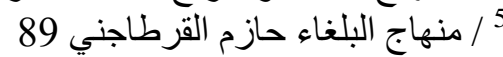

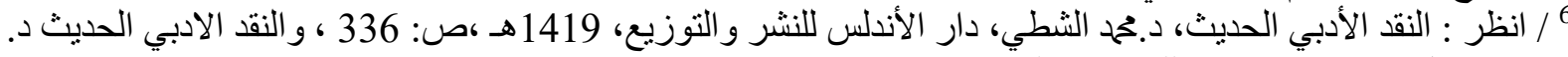

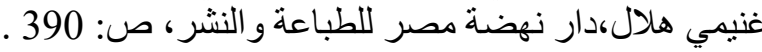


بالثعر و هو صدى الأول ونهج منه " 1 ، في حين أننا نجد لهذا الفضل جذورا

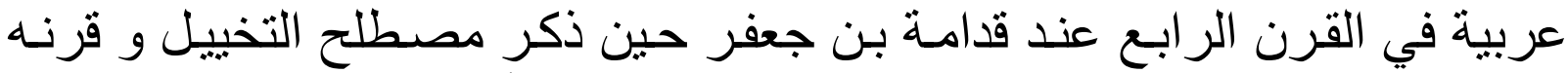

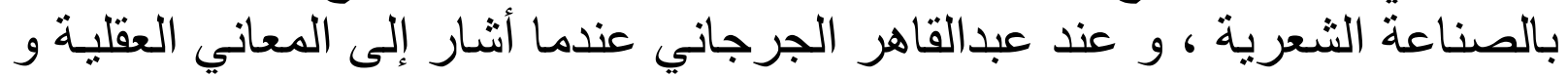

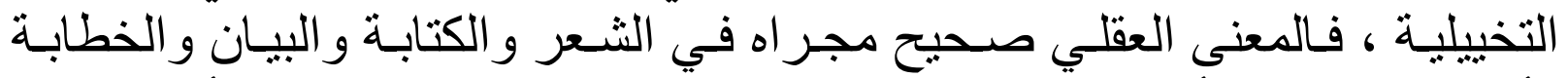

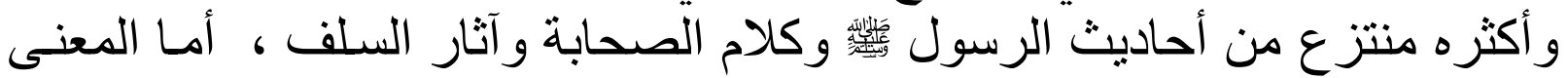

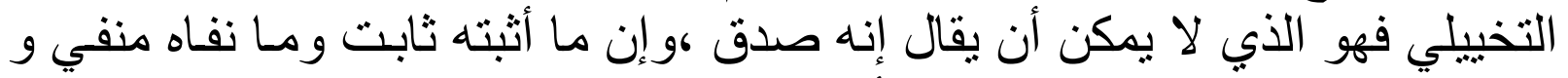

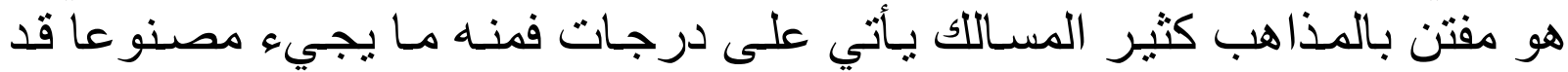

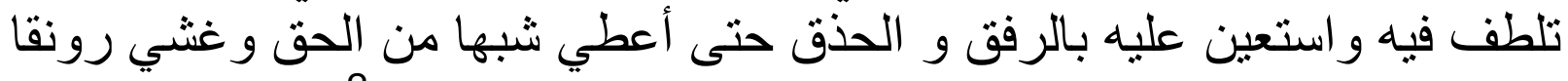

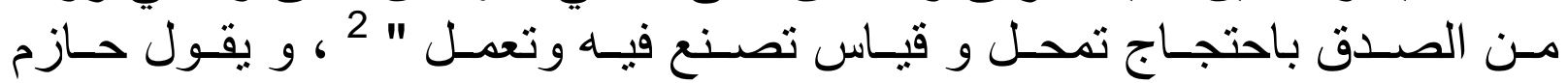

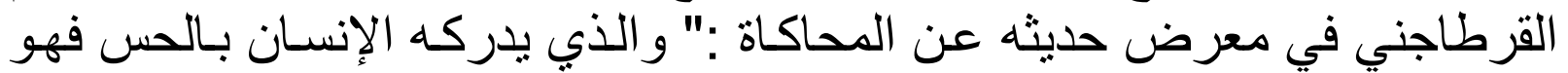

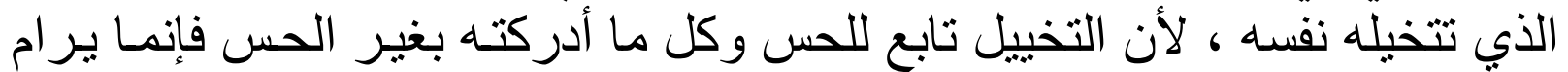

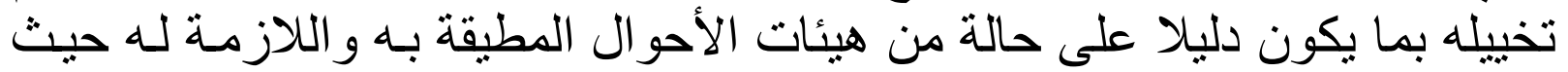

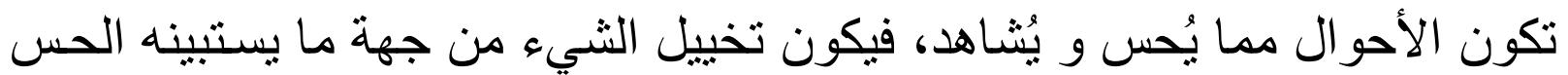

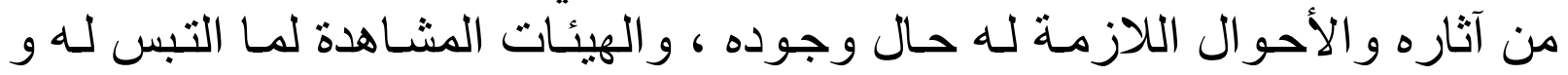

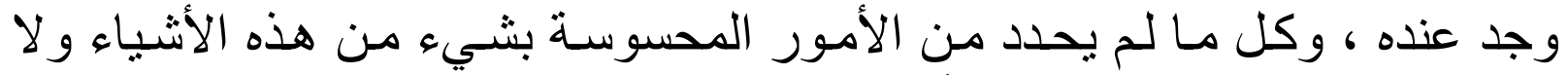

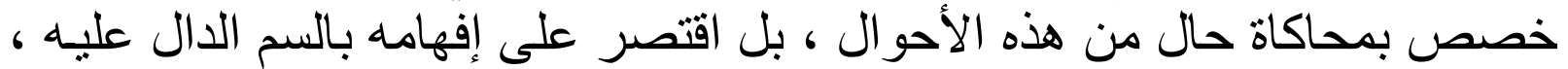

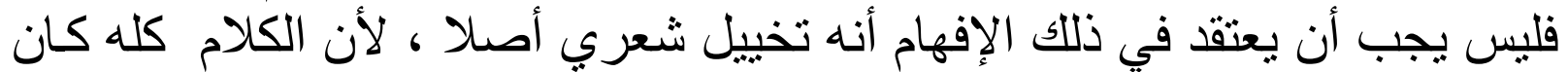

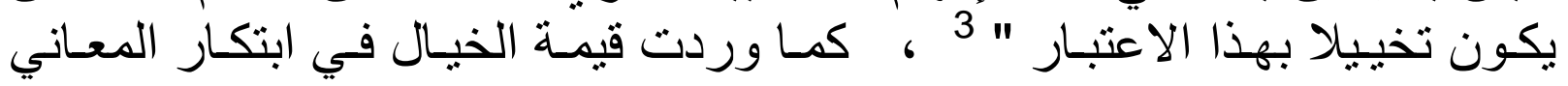

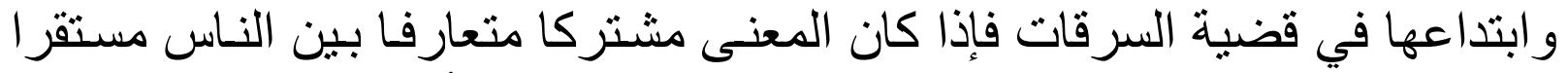

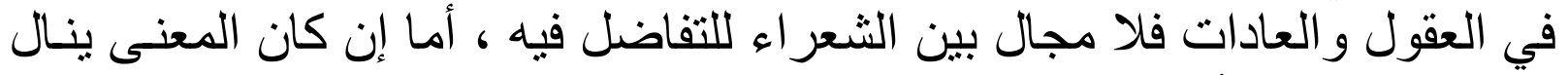

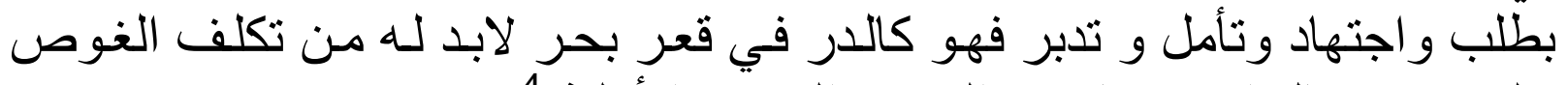

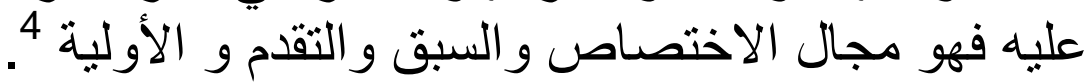
و بهذا العرض التاريخي المختصر لجذور ( الصـورة ) في الترات الثرات العربي

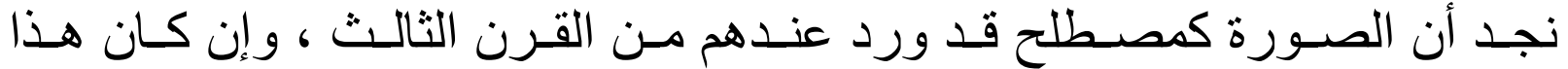

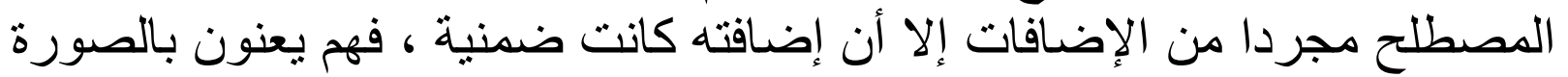

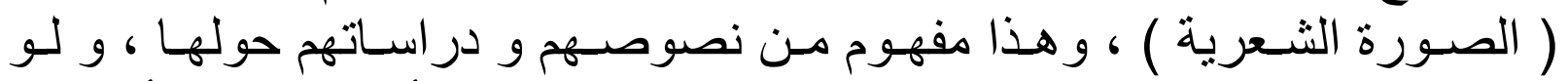

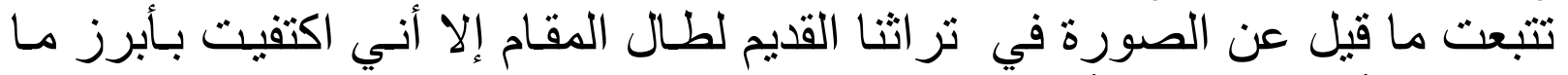

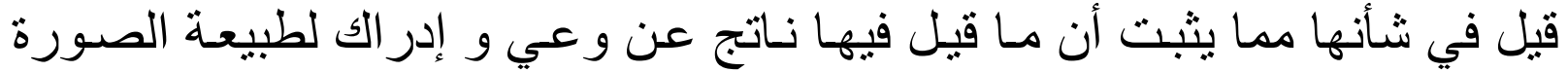

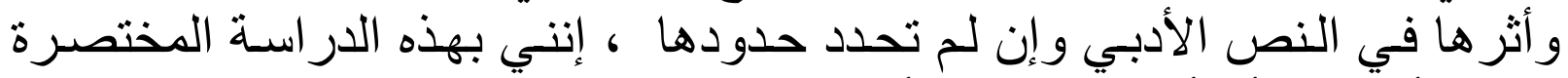

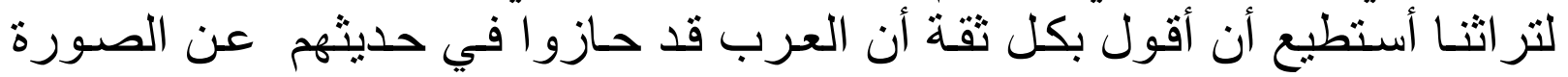


شأو ا عظيما بما بناسب طبيعة عصر هم و أدبهح ، لقد أدركوا الصورة بكل أبعادهـا

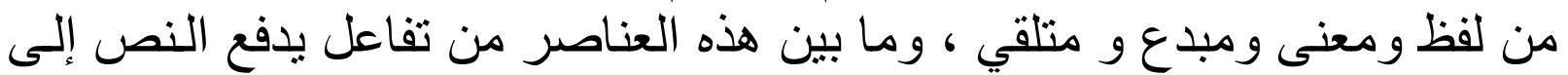

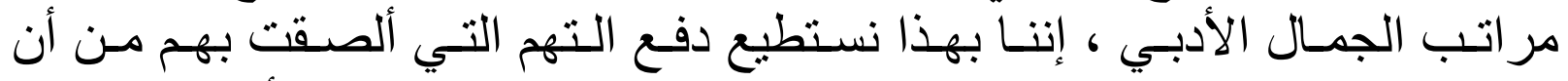
الصورة عندهم مقصورة على المجاز و الاستعارة، والتي مأهي إلا أدوات تستع التعين

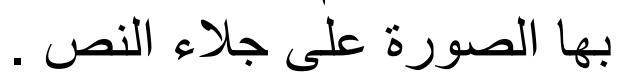

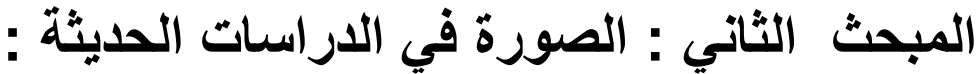

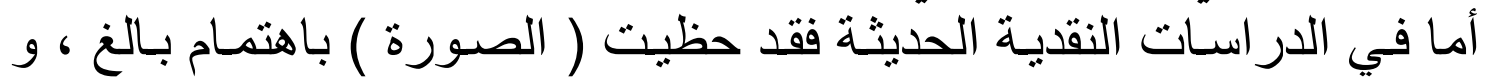

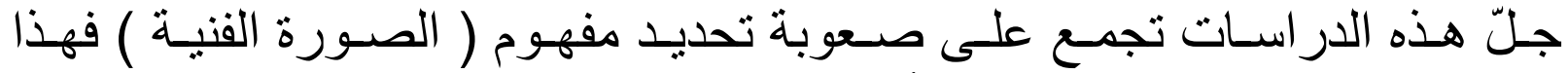

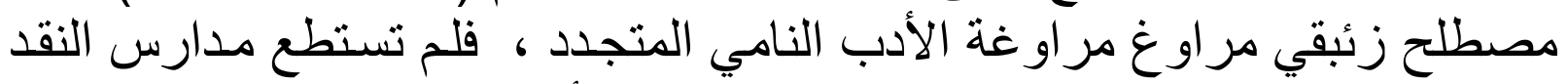

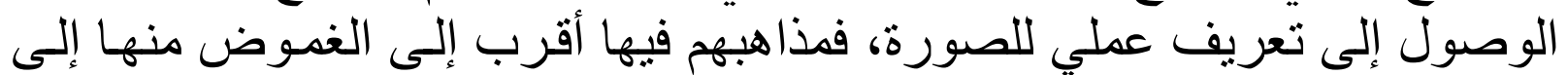

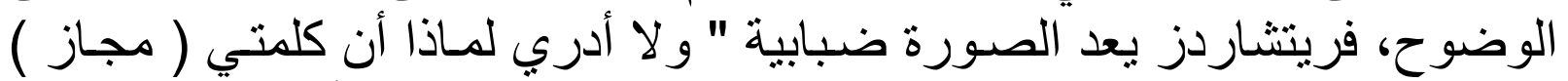

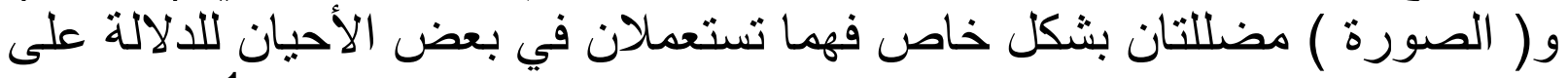

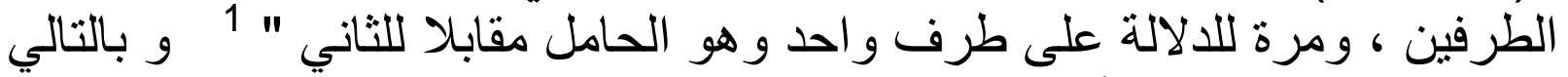

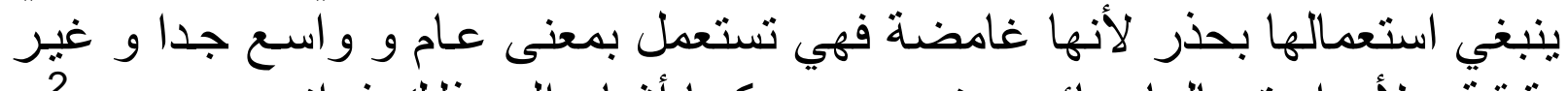

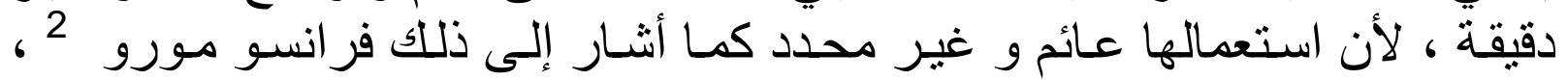

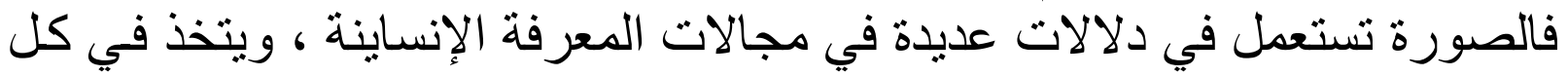

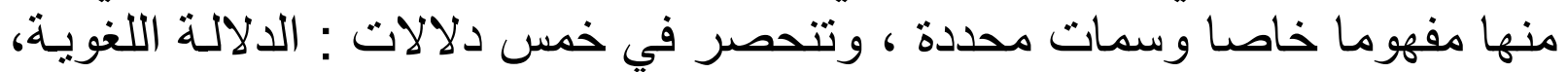

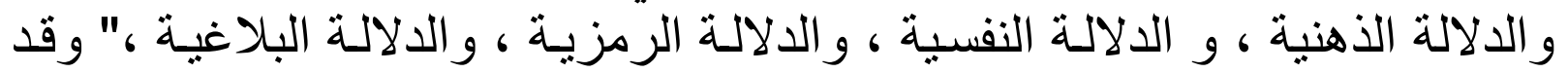

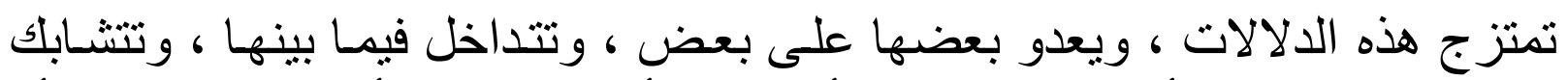

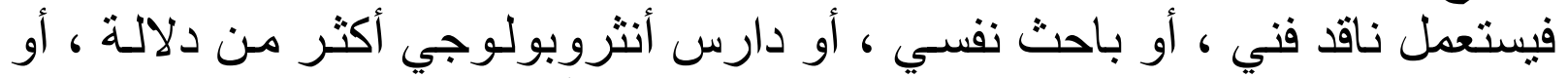

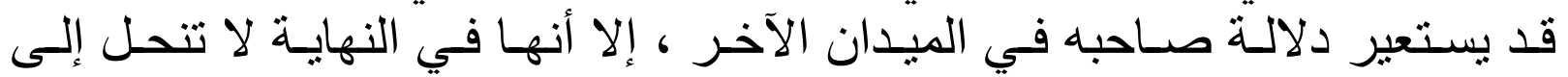

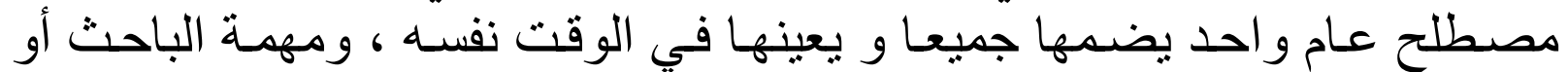

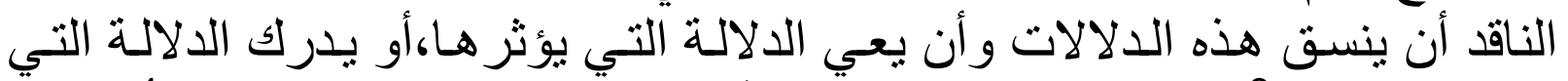

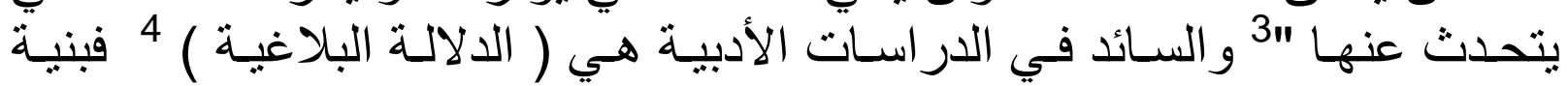

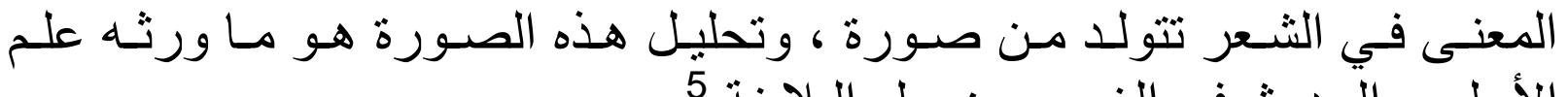
الأسلوب الحديث في الغرب لتوب عن علم البلاغة 5 إن النقد الحديث ينظر إلى الثعر على أنه هو الثنعور نفسه ، إنها إنه تقليد للعـالم

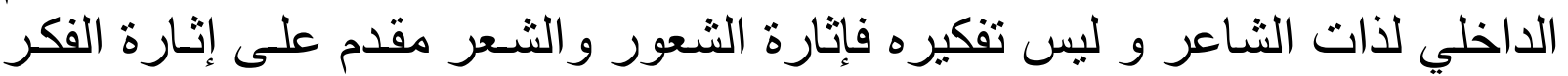

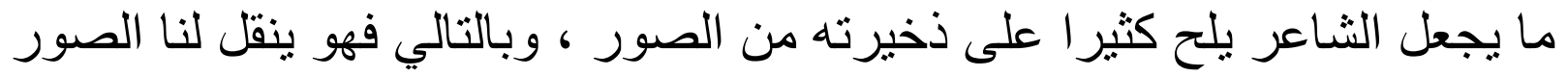

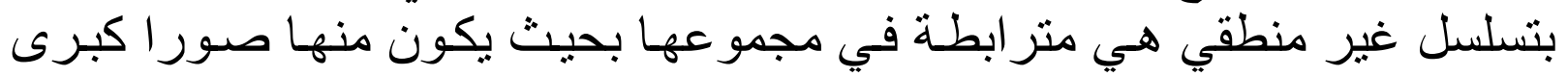


تعين على كثـف أعمق من المعنى الظـاهري للقصيدة 1 ،مـن هنـا يـرى أندريـه

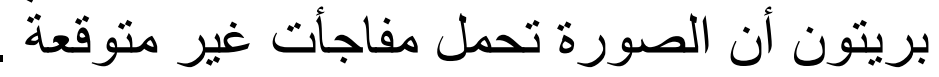
و إذا كانت الكلاسيكية تدعو إلى سيطرة العقل على على الأدب وتقيهيم الأعمـال

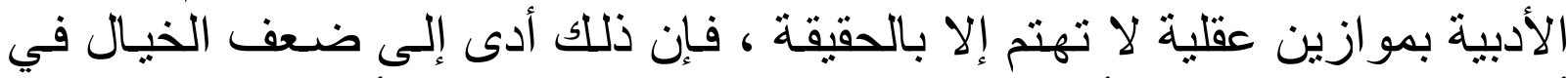

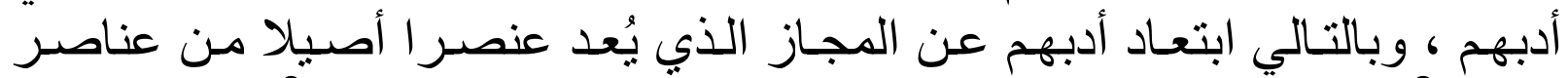

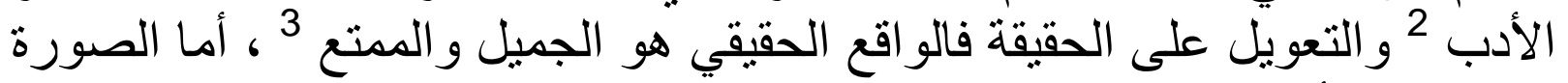

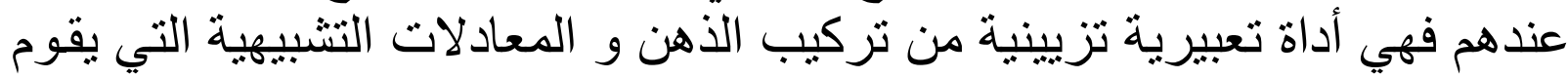

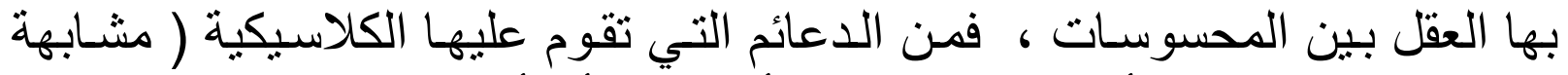

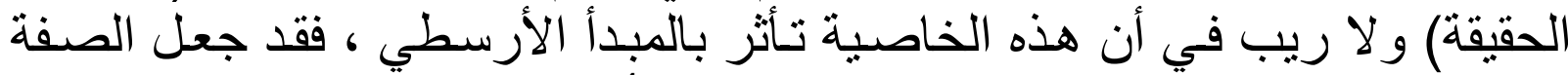

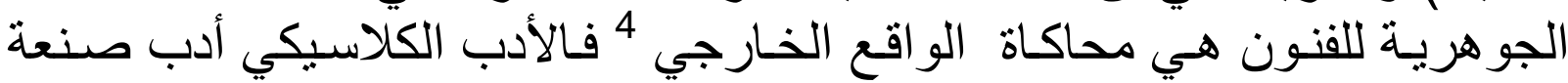

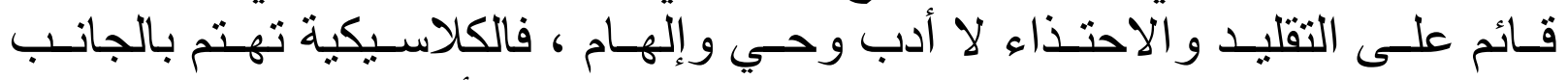

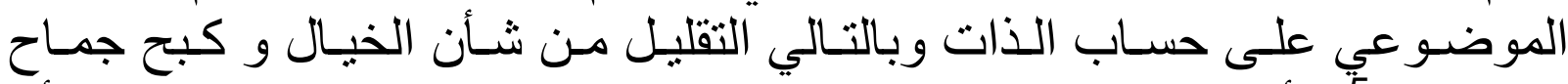

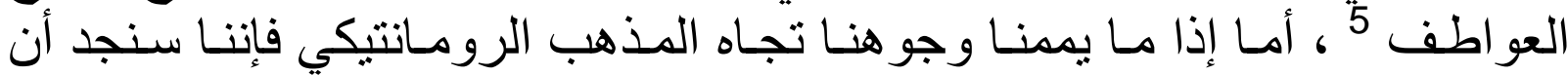

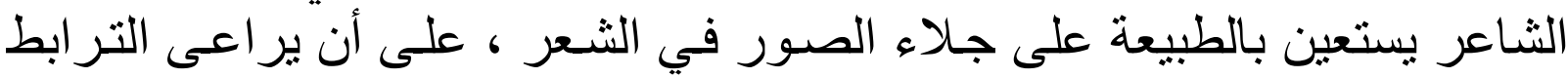

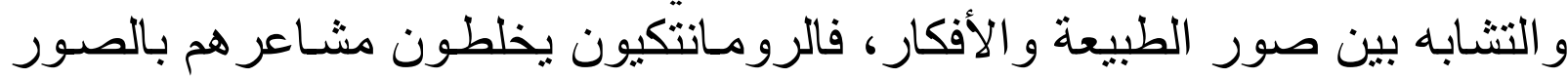

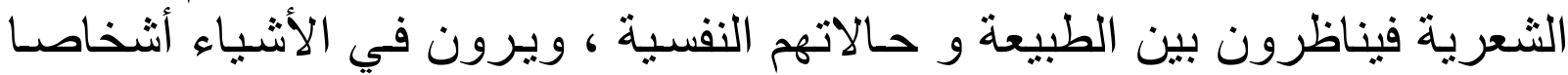

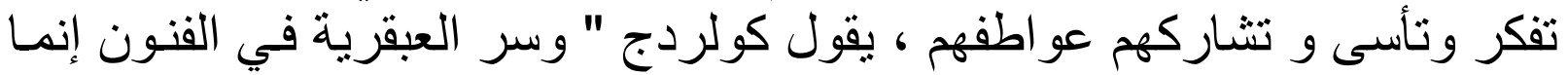

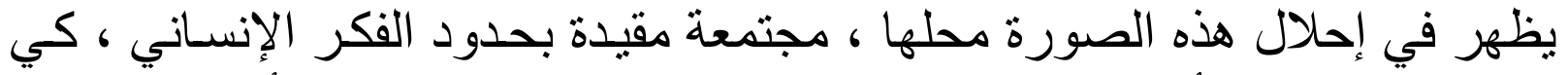

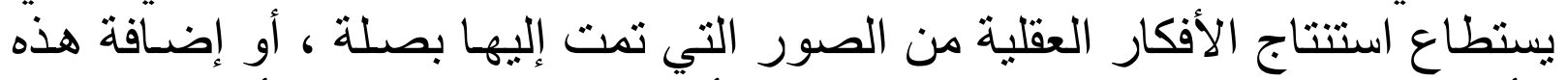

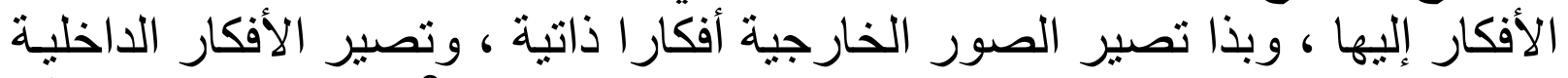

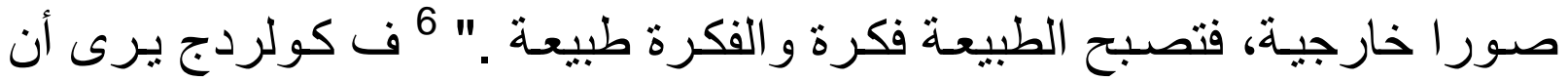

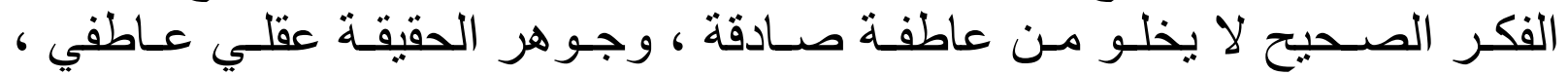

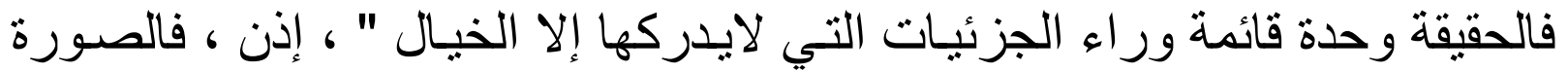

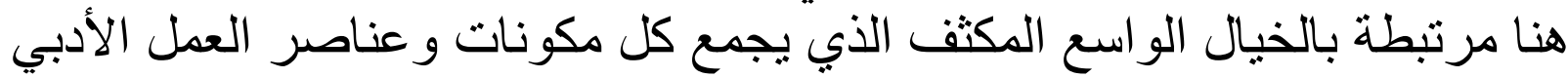

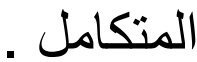

إن الصورة الثعرية عند الرومانسيين لم تقتصر على علاقيات بسيطة قائمـة

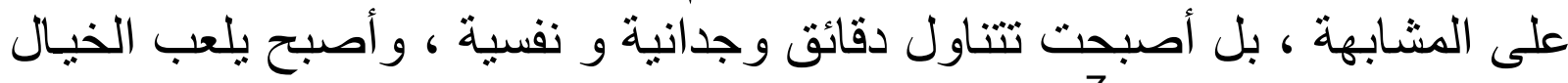

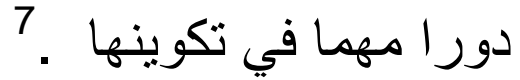

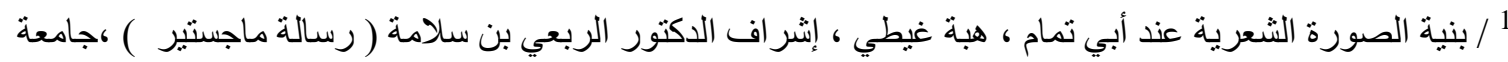

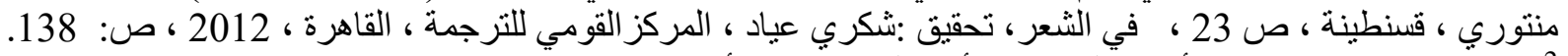

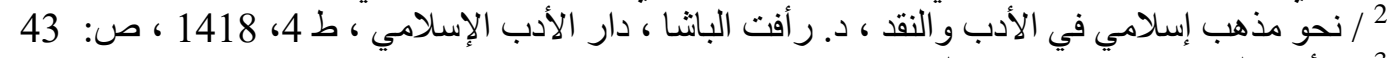

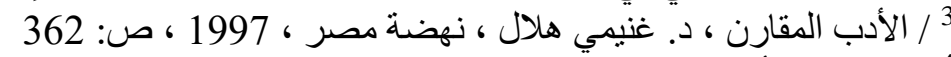

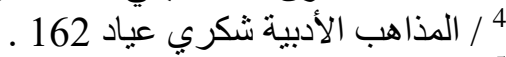

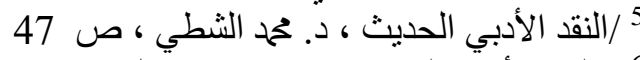

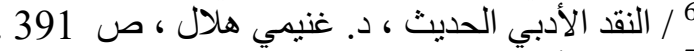

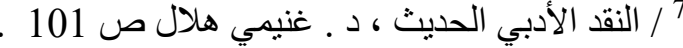




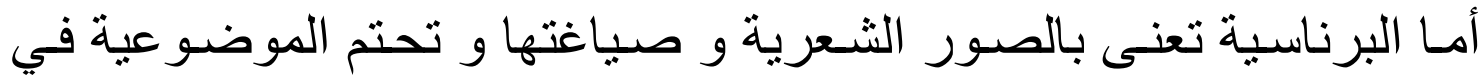

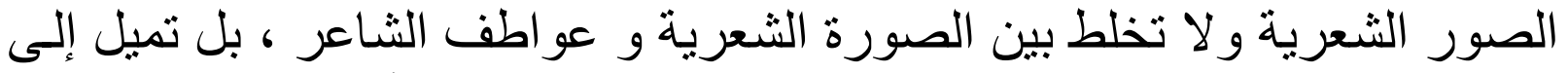

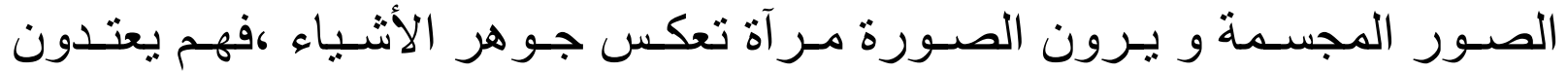

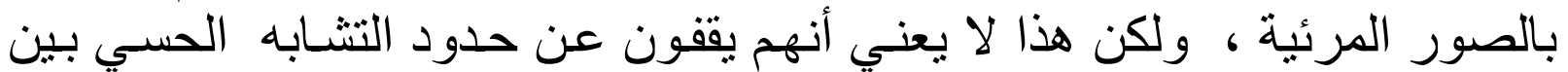

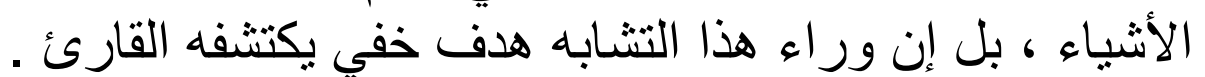

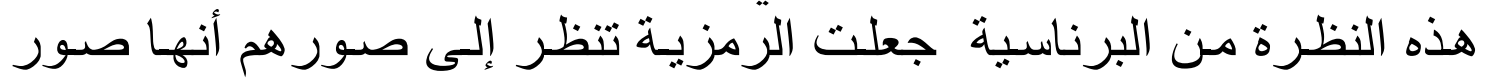

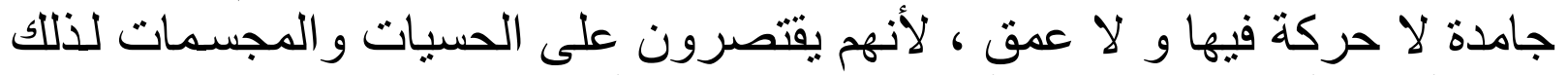

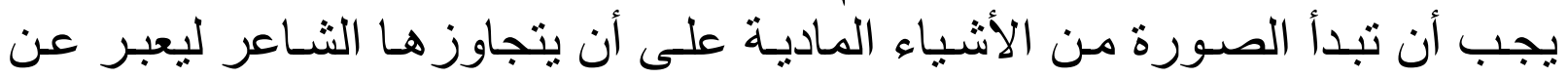

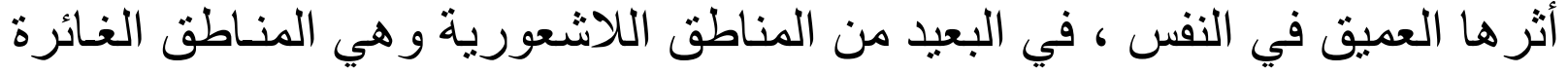

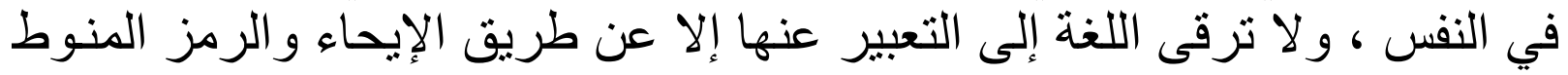

الصورة الرمزيـة ذاتيـة لا موضو عية كما عند البرناسبين ، و هـي تجريديـة تتنقل من المحسوس إلى المعقول ، لا تعتد بالعـالم الخـارجي إلا بمقدار مـا تجعلـه

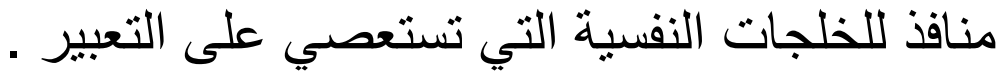

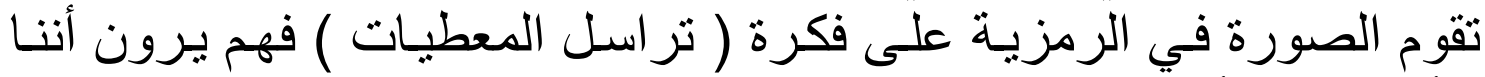

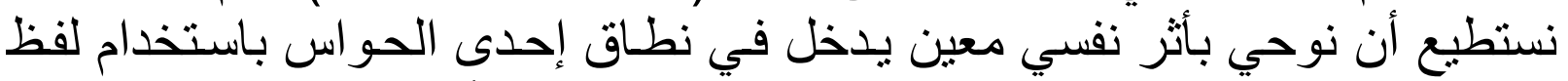

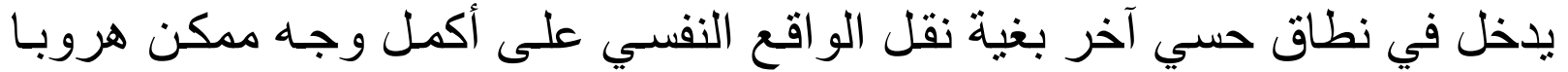

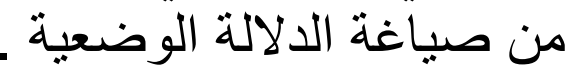

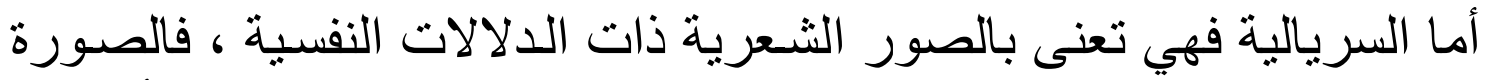

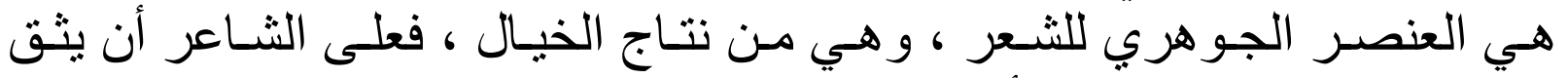

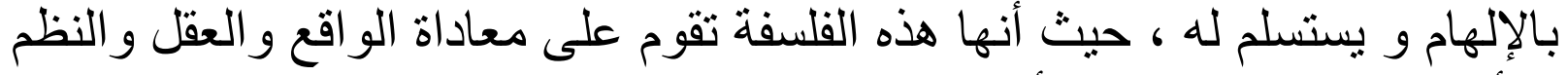

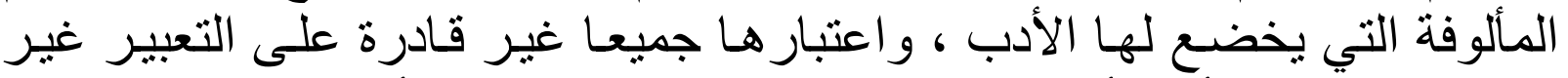

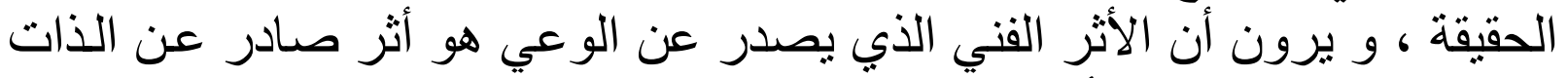

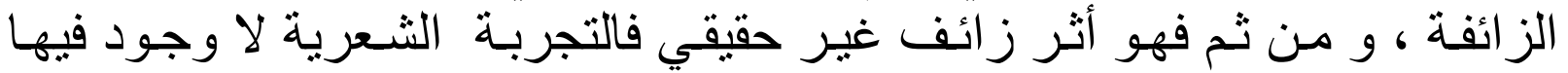

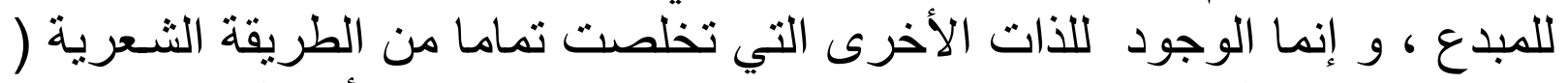

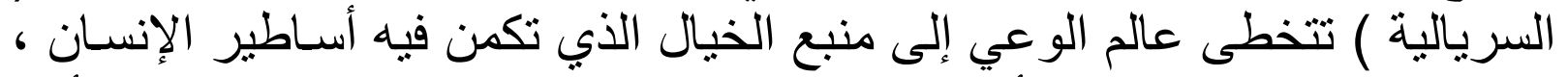

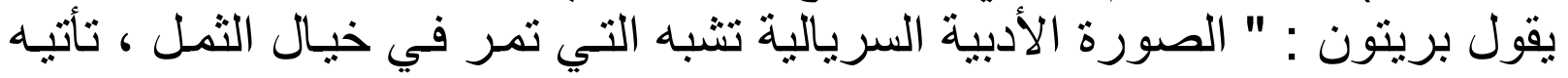

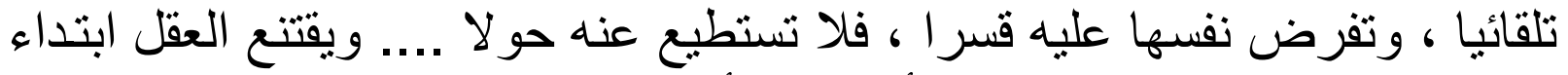

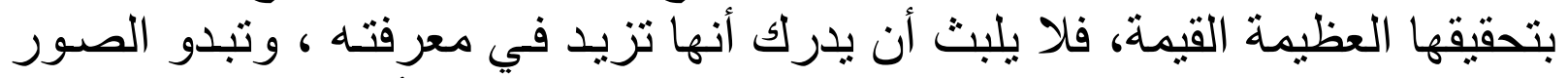

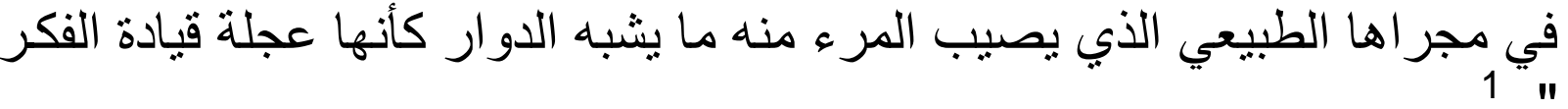




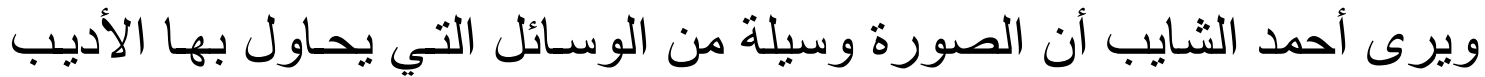

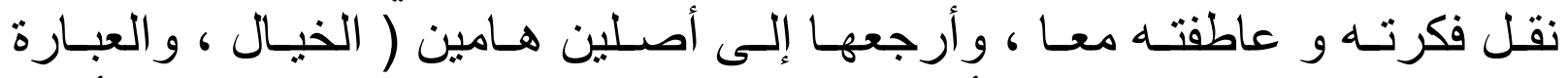

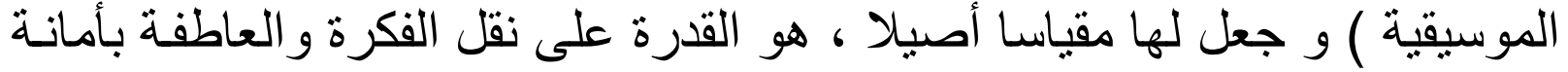

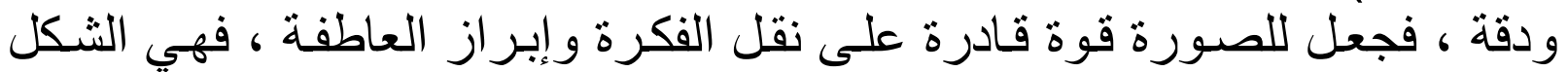

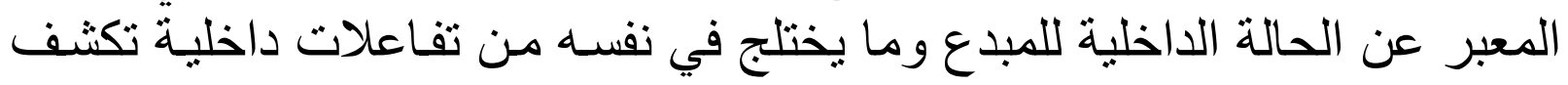

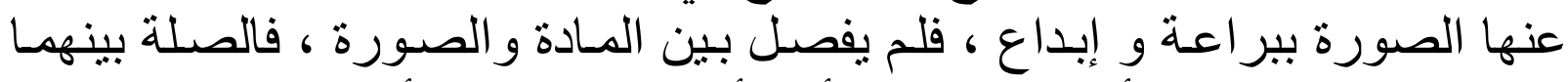

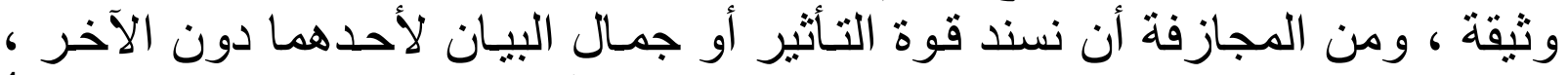

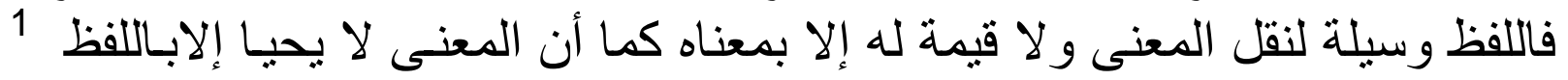

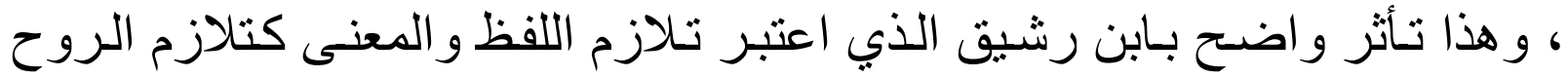

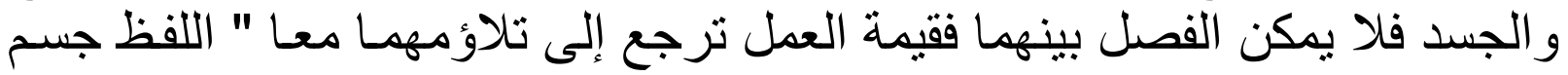

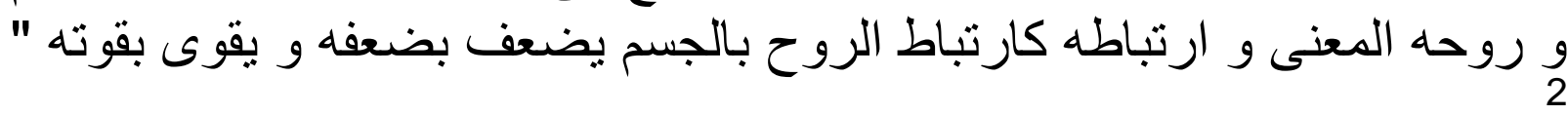

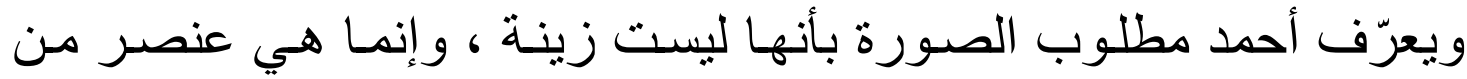

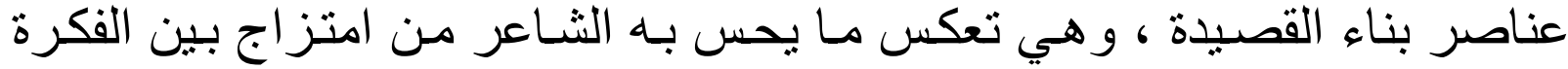

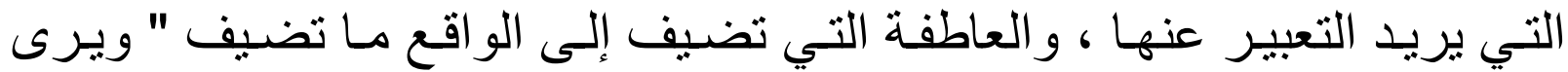

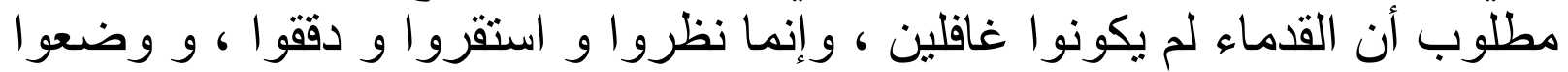

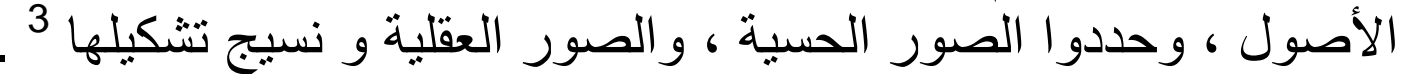

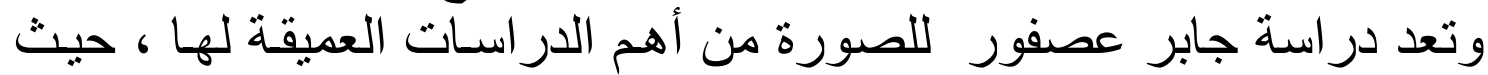

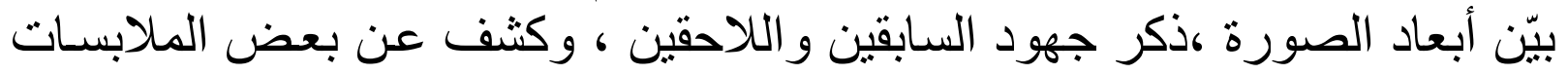

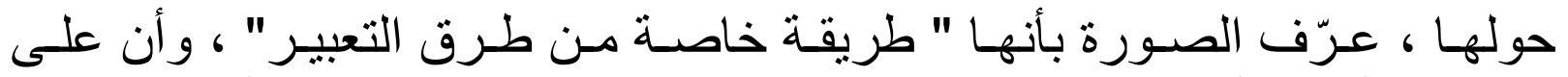

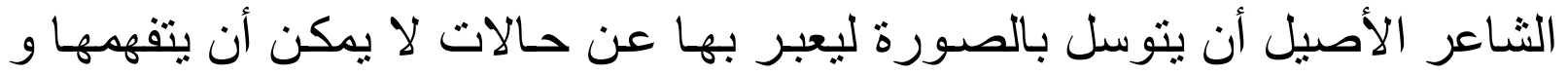

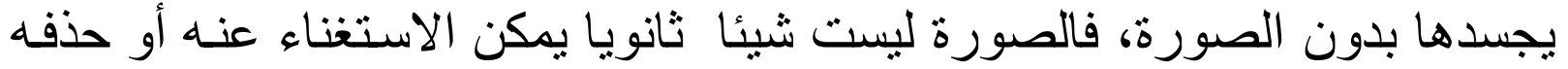

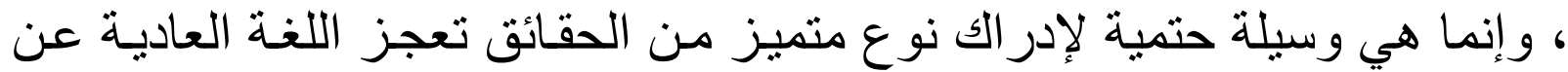

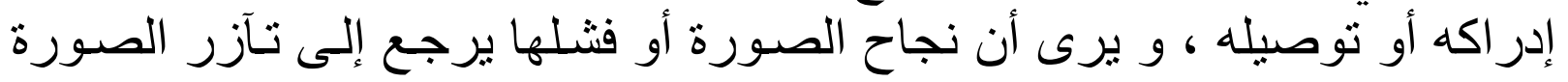

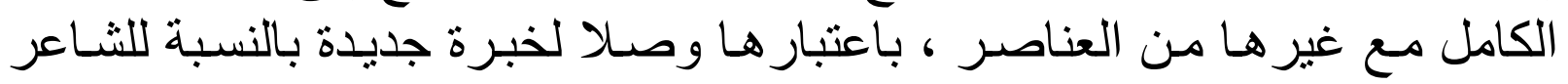
الذي بدرك ، و والقارى عئ الذي يتلقى .

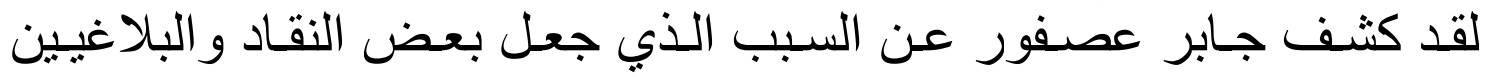

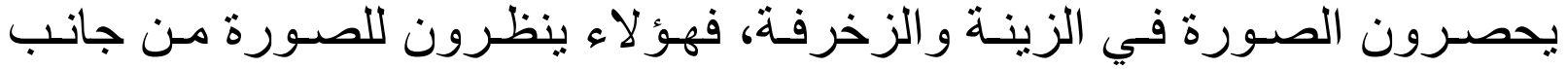

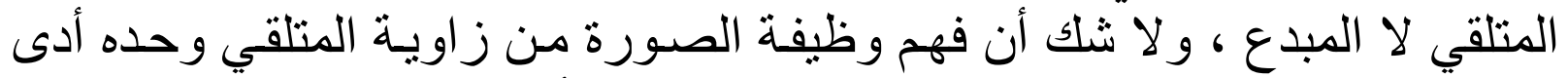

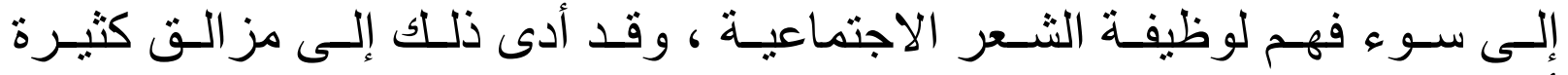

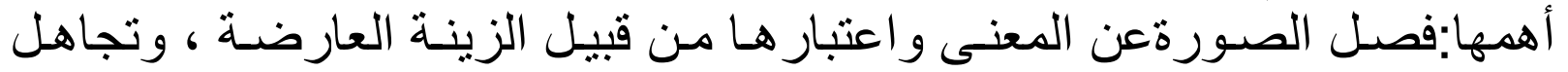


الضرورة الداخلية الملحة التي تدفع الثاعر إلى التفكير و التعبير بالصورة ، و رد رد التها

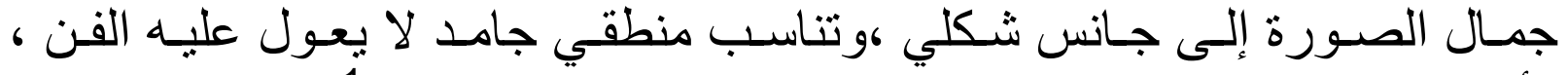

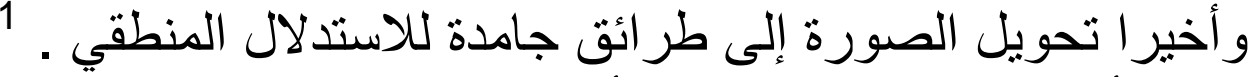

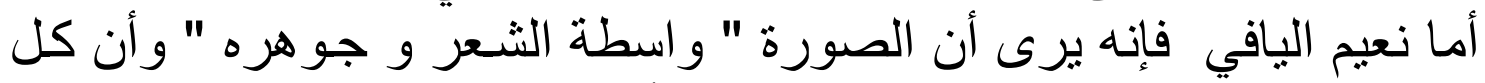

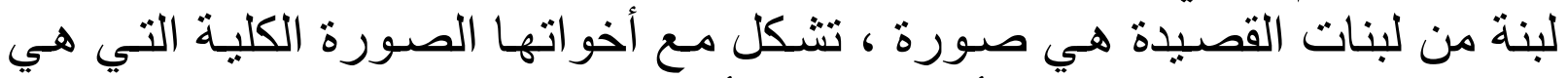

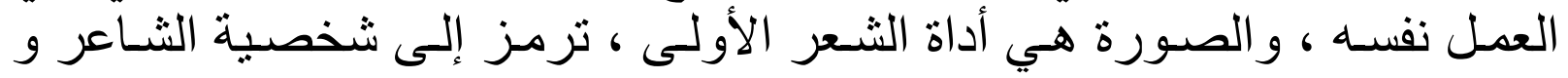

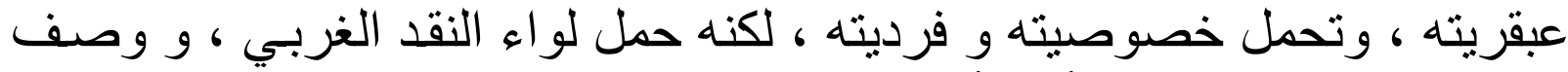

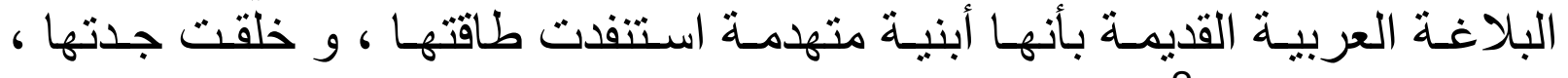
وطال عليها الزمن البعة 2.

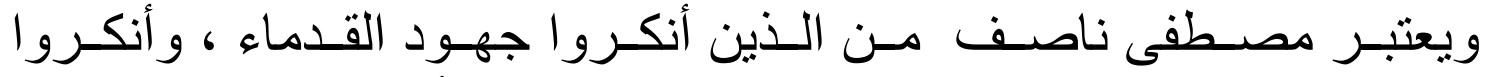

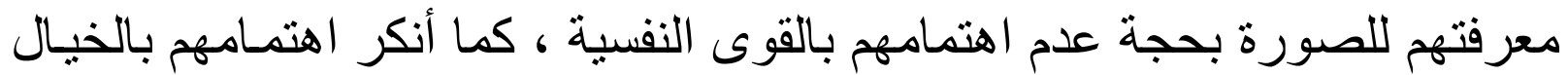

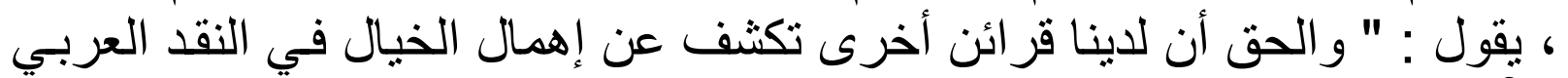

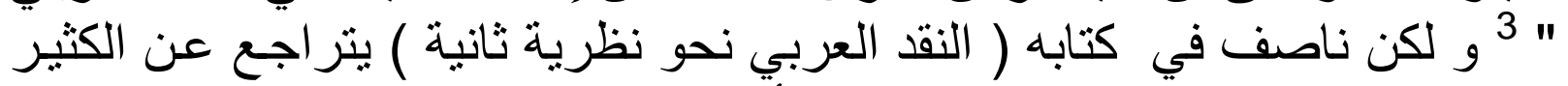

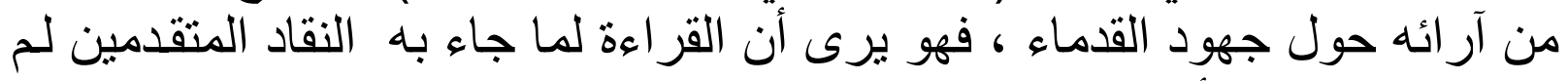

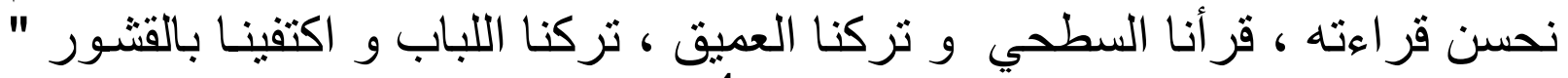

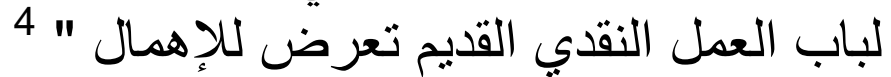

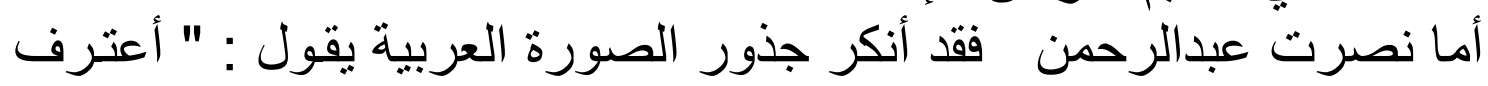
أن مصطلح الصورة من المصطلحات النقاية الو افدة التي ليس لها جذور فئور في النقد

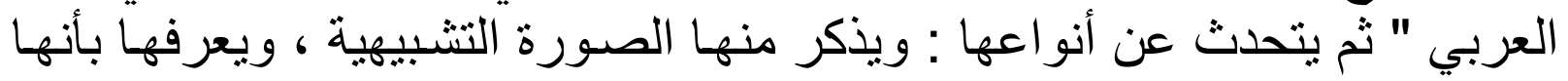

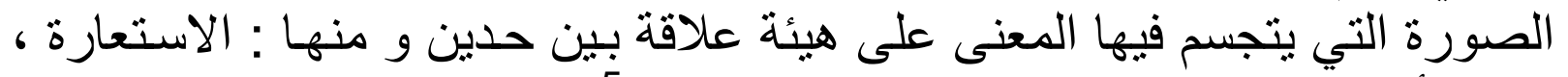

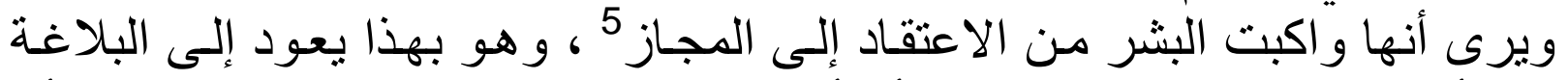

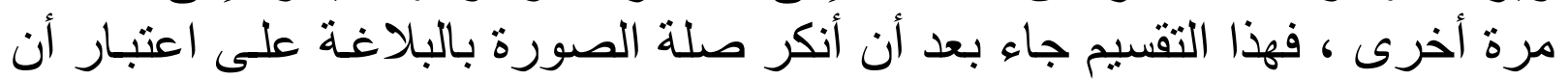

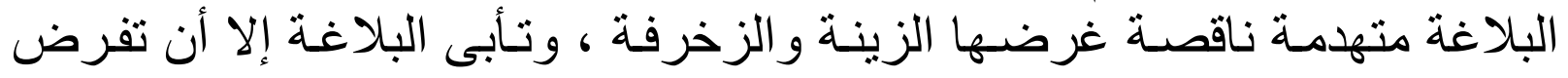

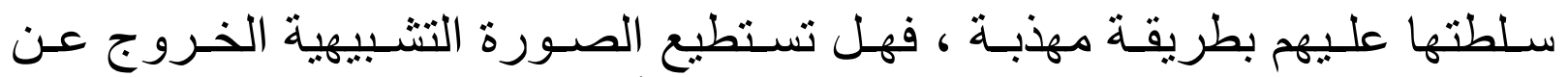

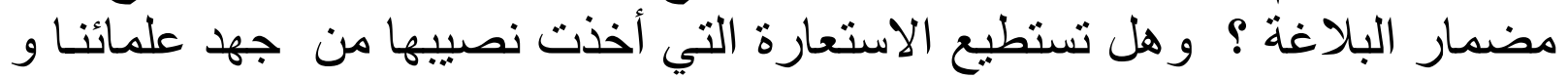

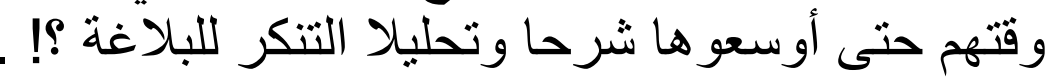

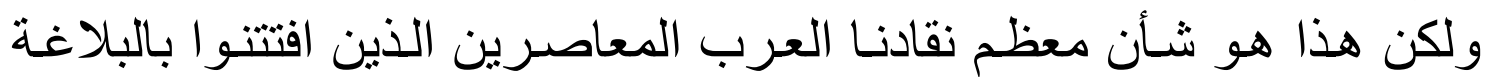

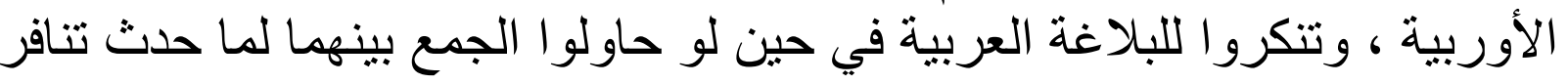

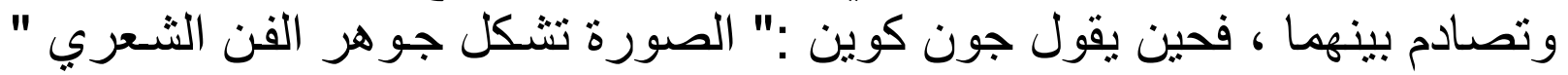


1 ، ألم يقل الجاحظ أن الثعر جنس من التصوير ... . ، و عندما قال كوزينوف :

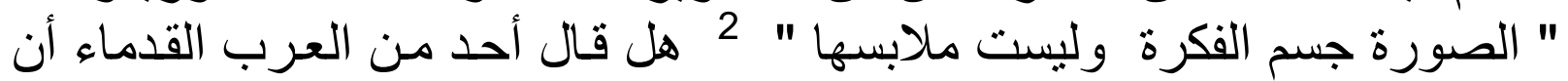

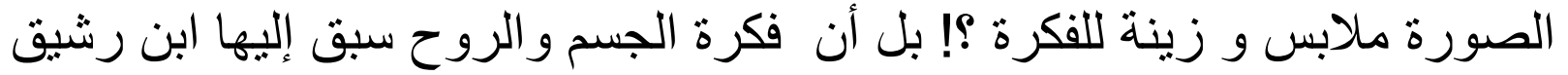

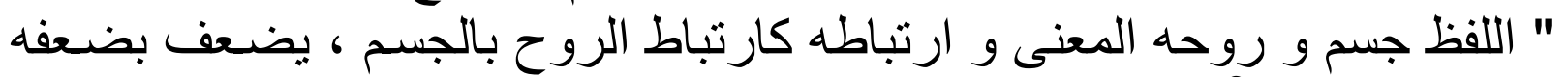

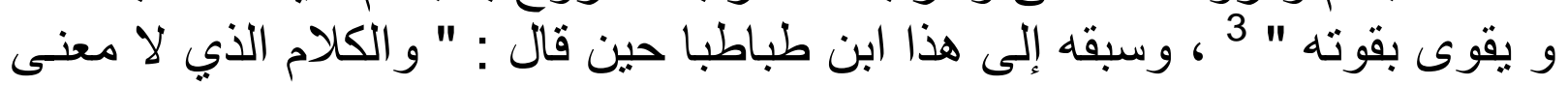

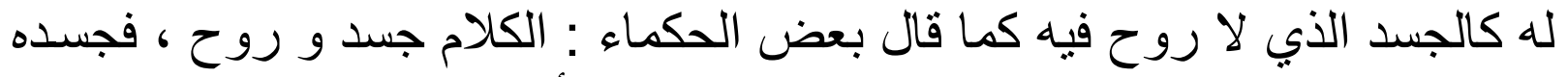

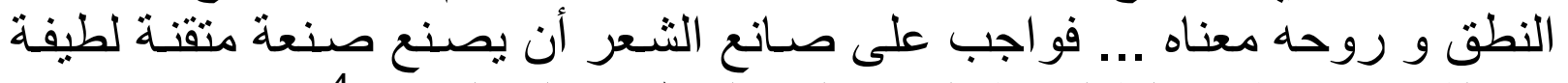

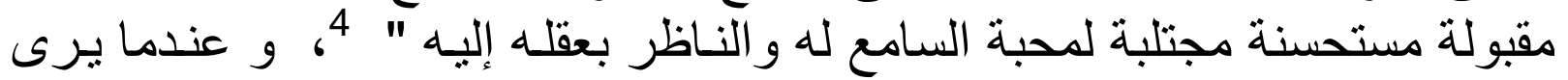

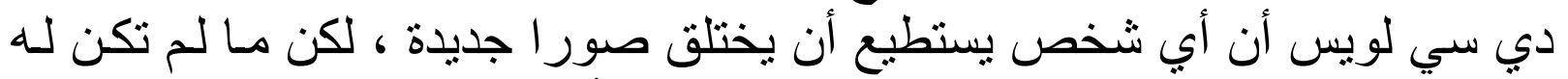

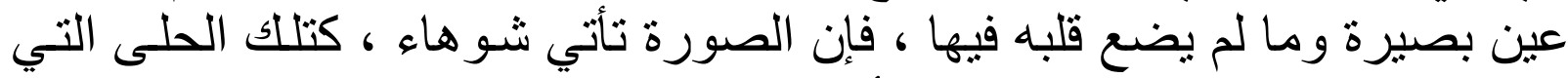

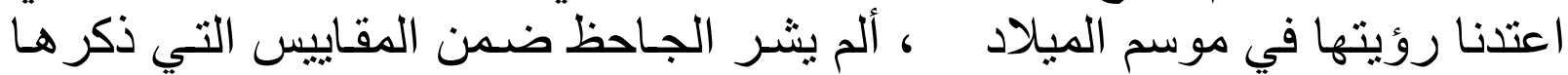

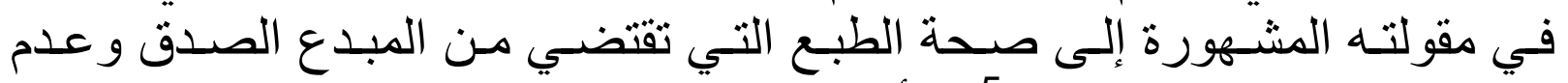

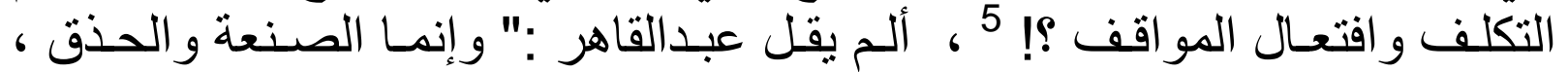

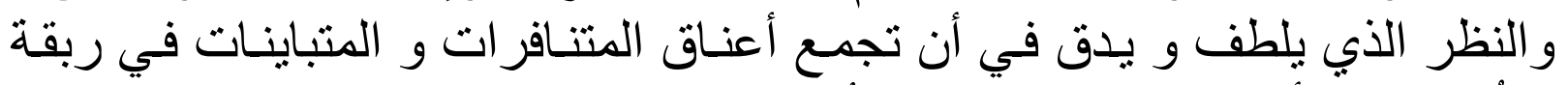

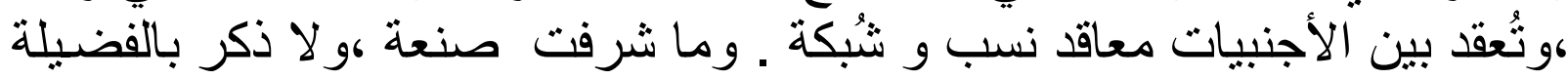

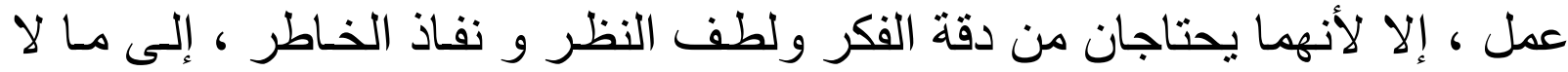

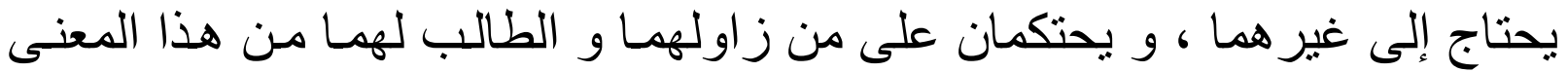

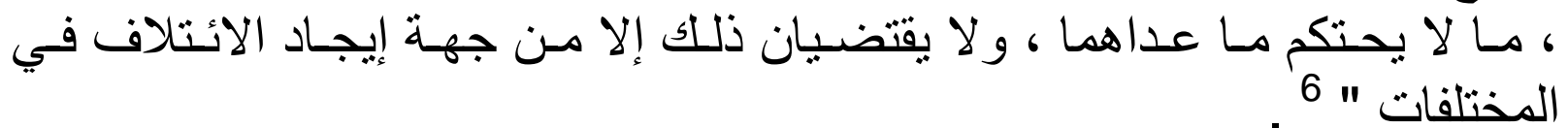

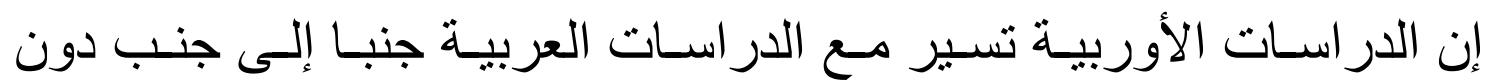

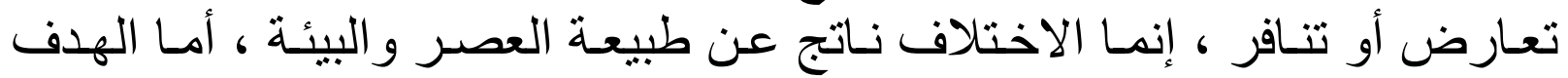

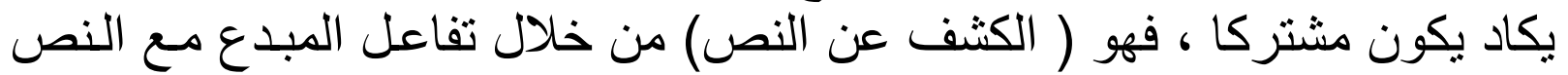

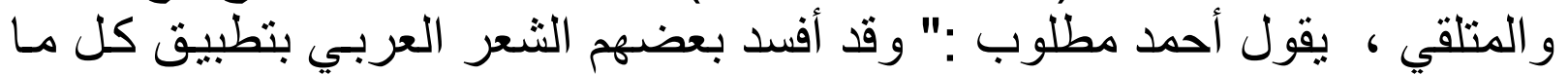

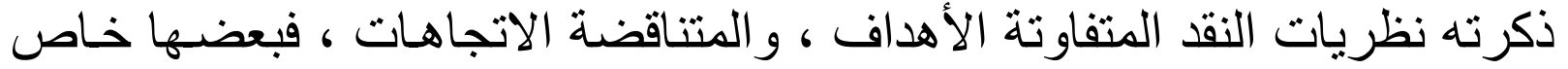

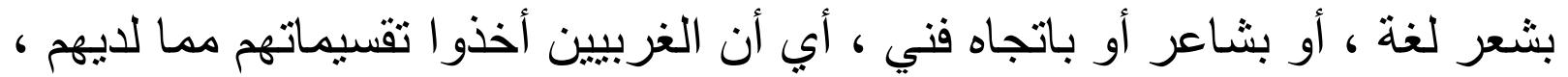

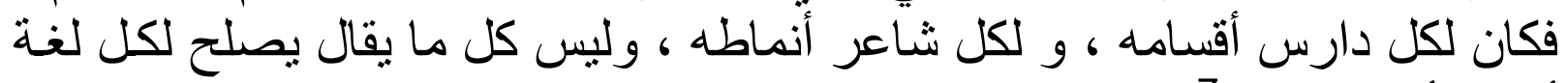

\section{المبحث الثالث: الاستعارة ونمط الصورة :}

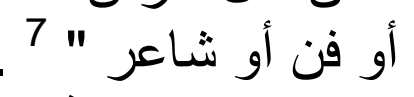

1 1 / مقال ( سر التمايز الشعري ) نايف الرشدان | 2 / المرجع السبابق الثيايز 3 / العمدة 1/ / 124

4 / عبار الثعر ، لأبي الحسن محد بن أحمد بن طباطبا ،تحقيق د. عبدالعزيز المانع، دار العلوم ، 1405 هـ ، ص : 17 ، 


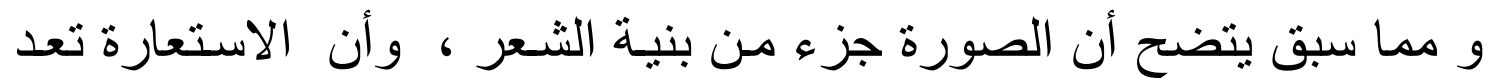

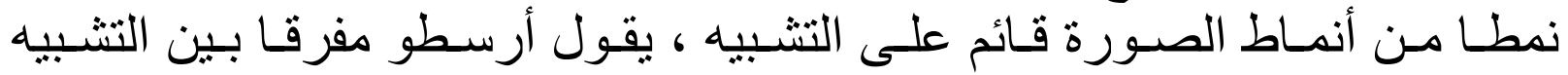

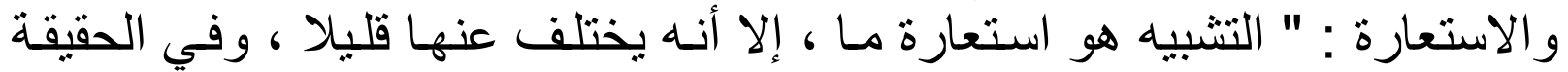

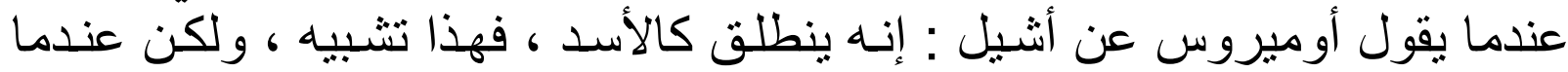

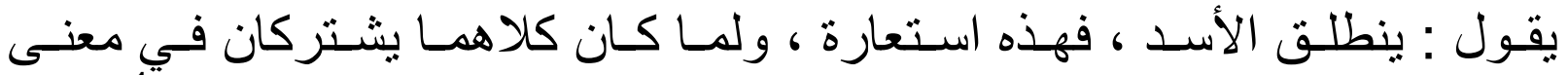

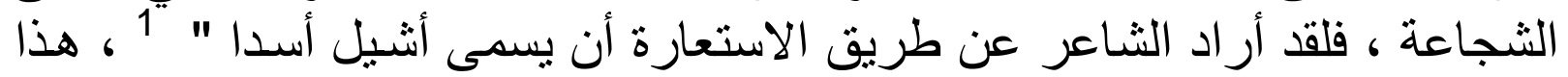

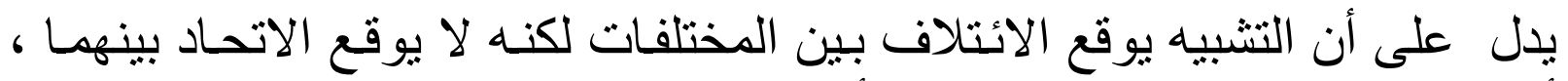

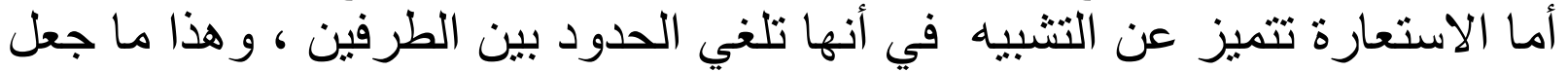

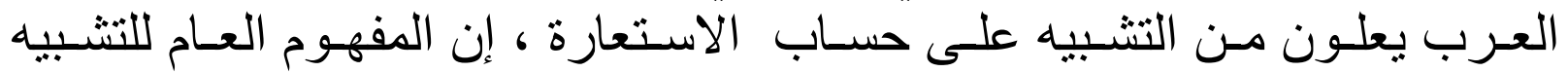

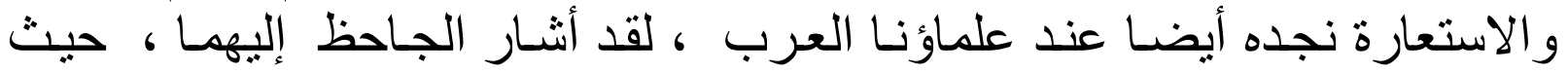

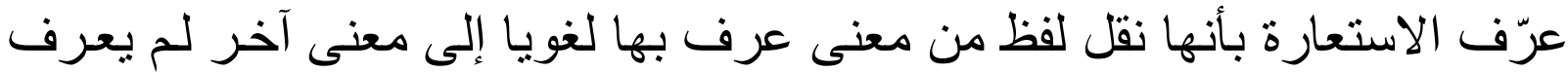

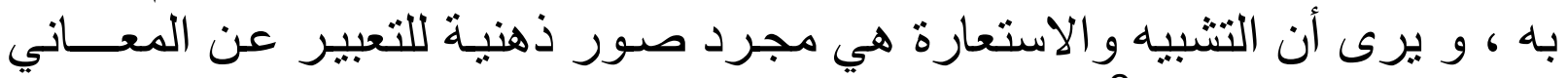
المجردة بقو الب حسية 2 ، يقول الجاحظ التهارة في تحليل البيت :

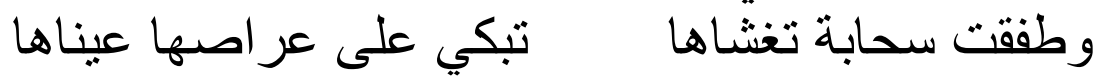

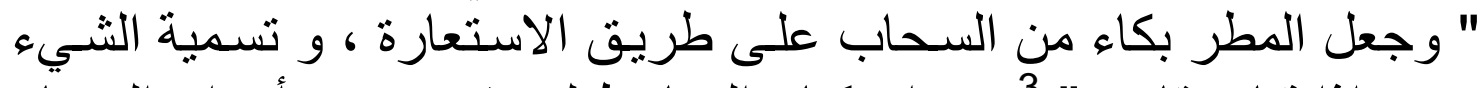

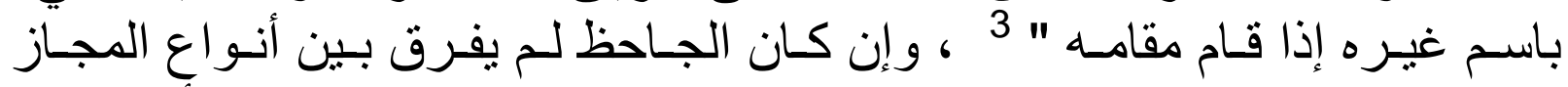

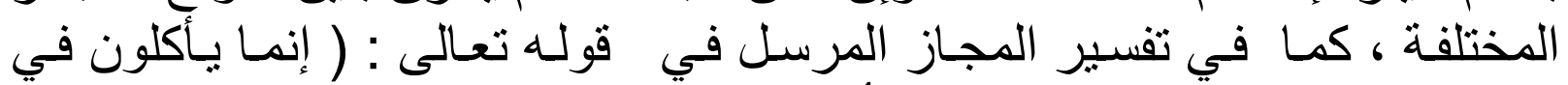

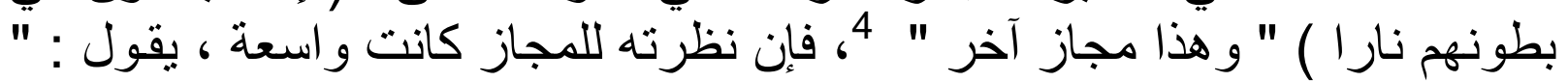

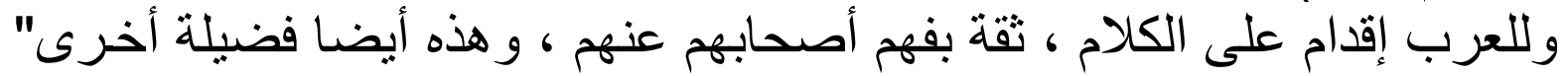

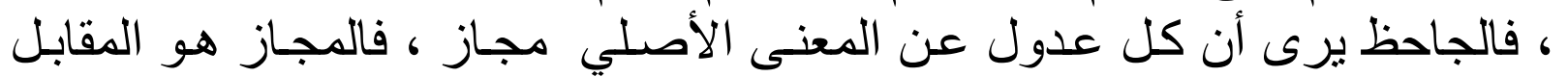

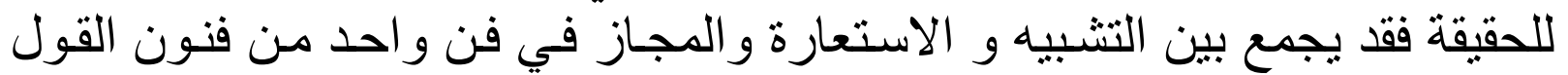

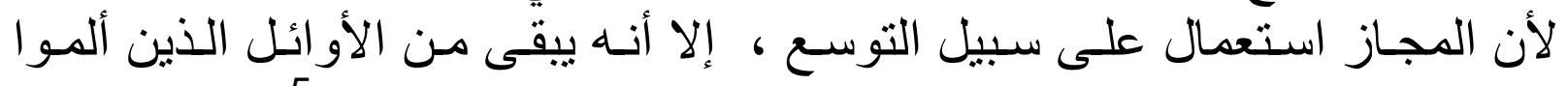

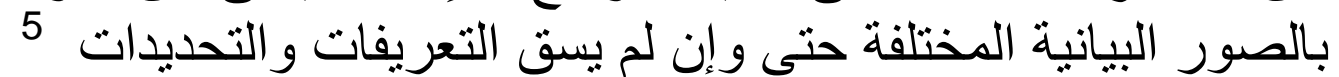

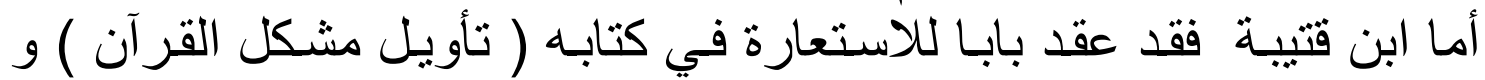

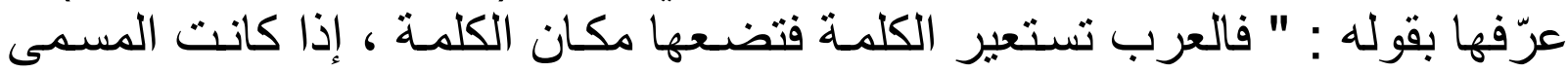

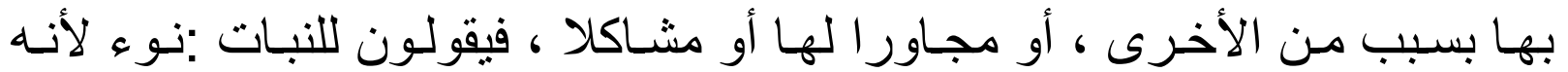

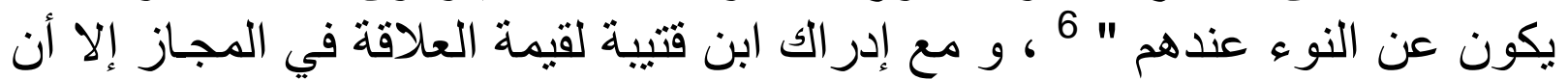

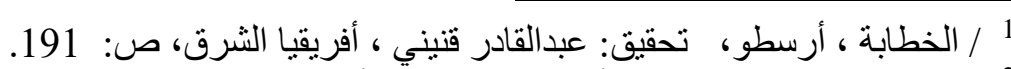

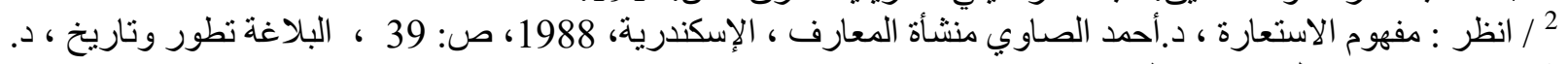

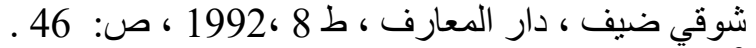

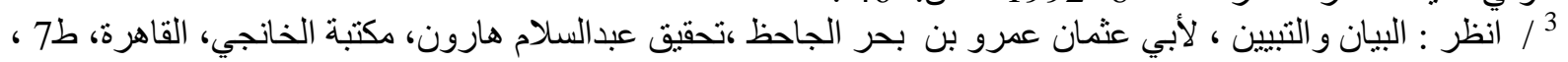

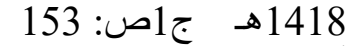

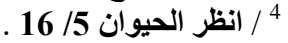
5 6 ، 6 / تأويل مشكل القَر آن، لأبي محمد عبدالله بن مسلم بن قتيبة ،تحقيق إبر اهيم شمس الدين ، دار الكتب العلمية ، بيروت ، ط1

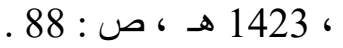




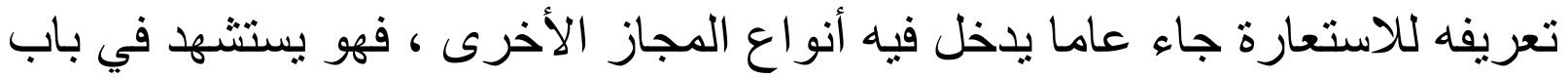

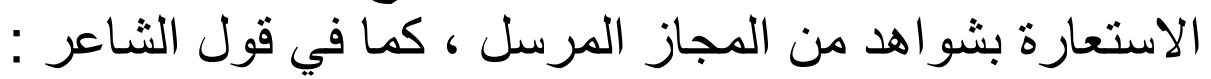

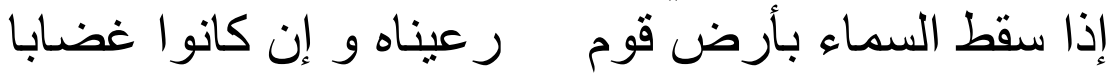

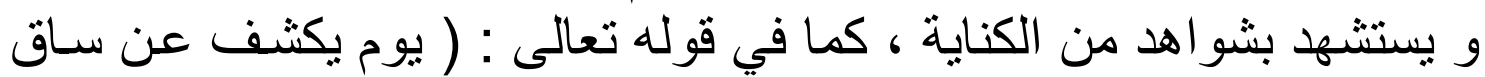

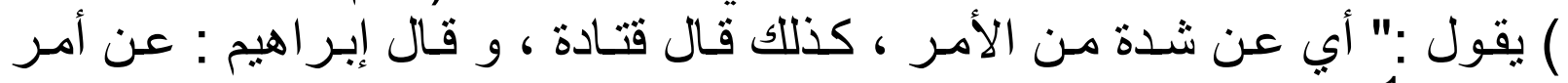

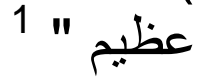

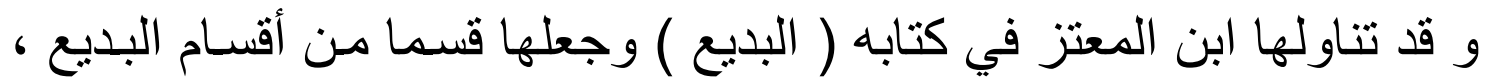

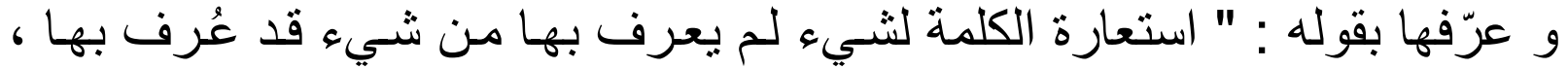

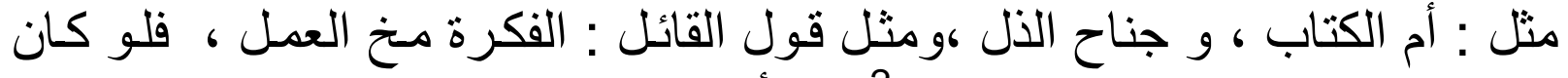

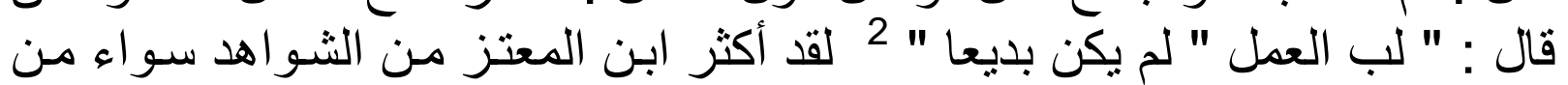

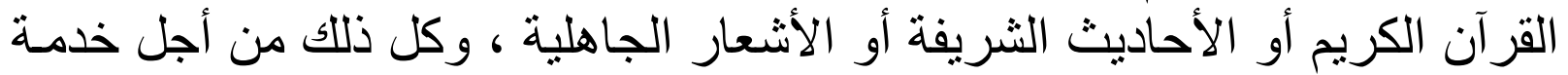

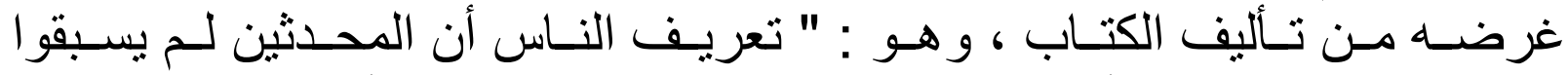

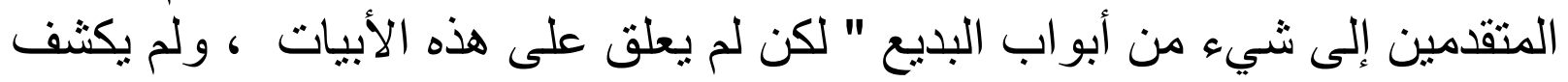

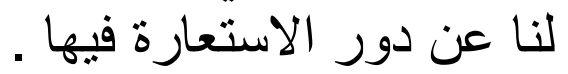

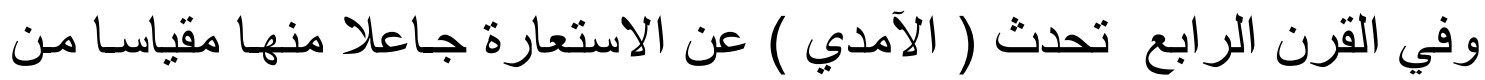

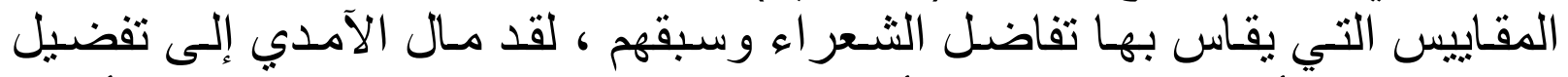

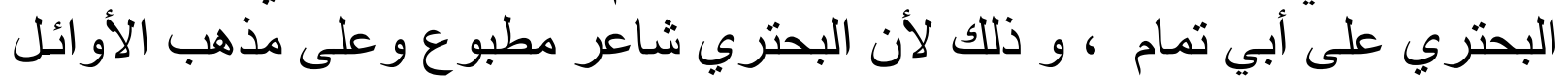

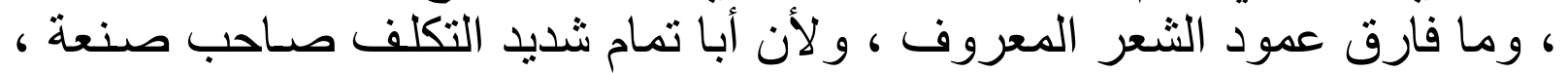

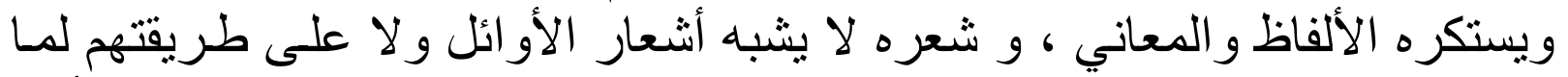

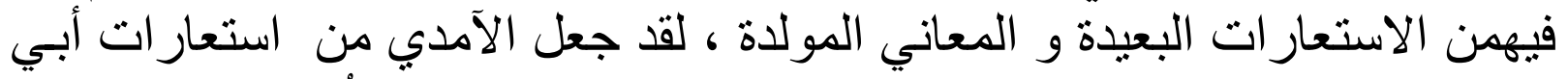

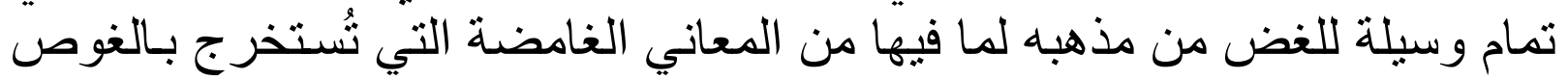

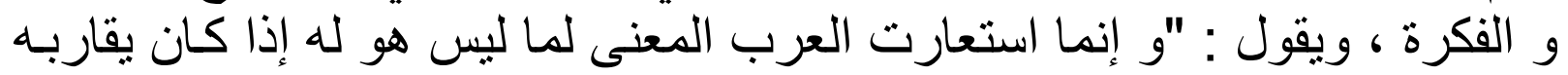

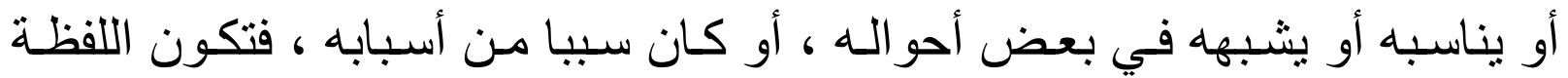

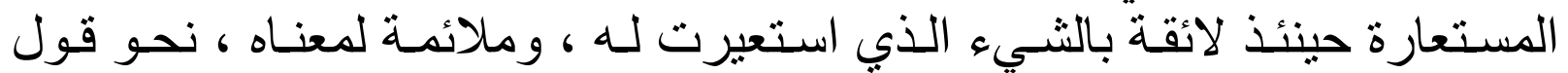

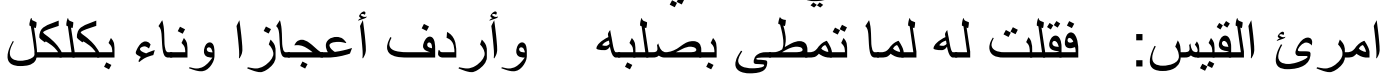

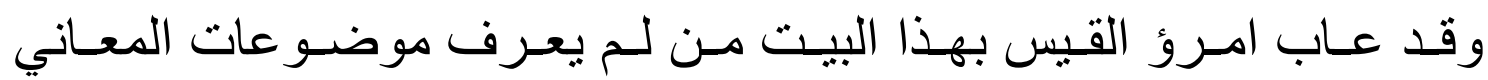

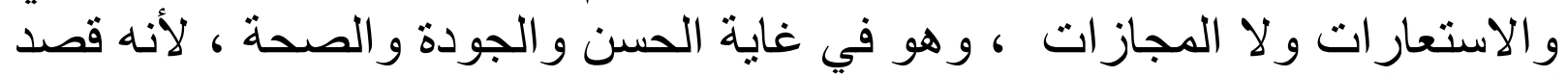

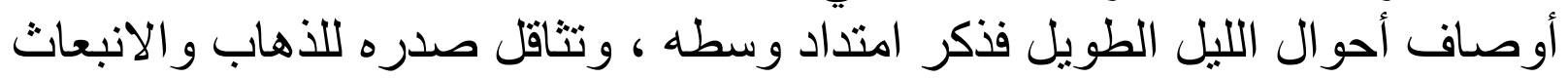

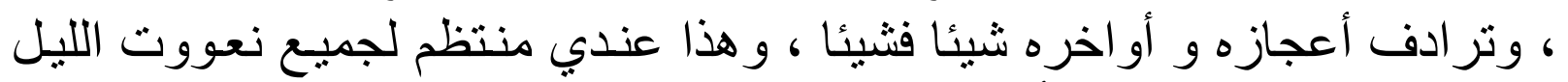

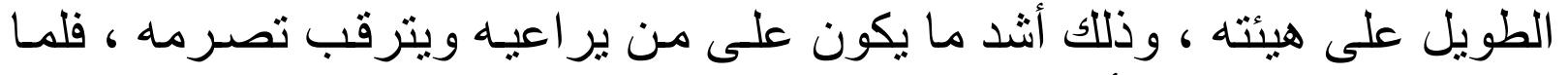

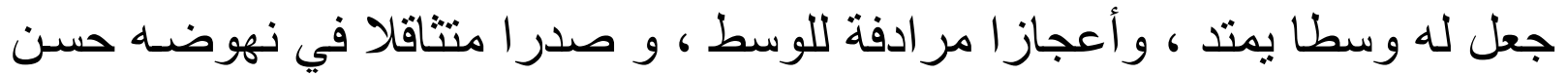

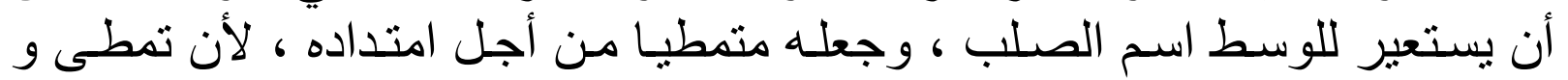




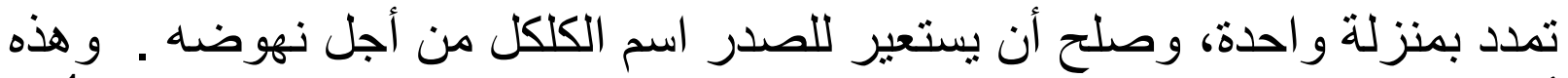

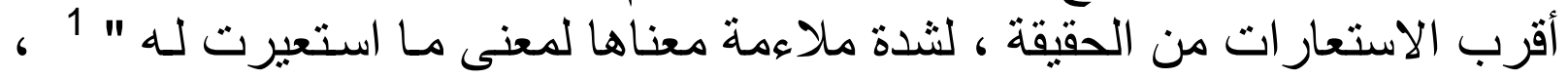

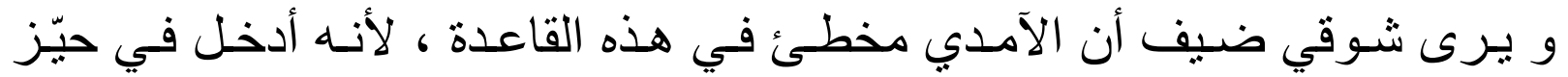

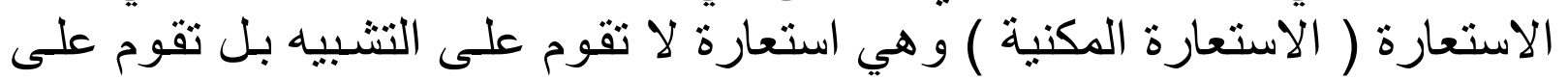

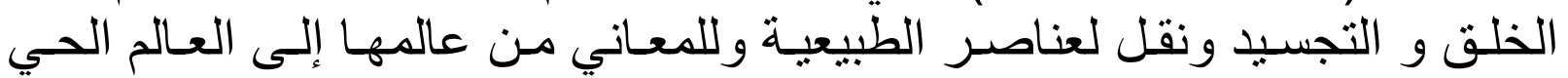

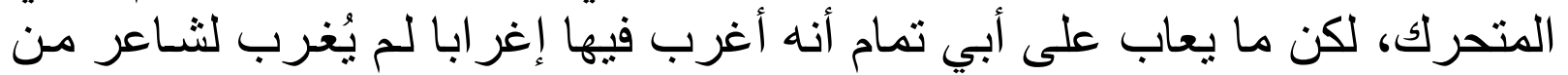

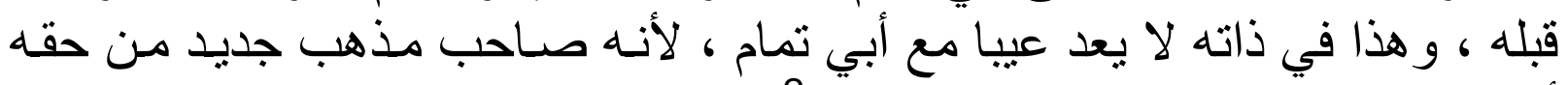

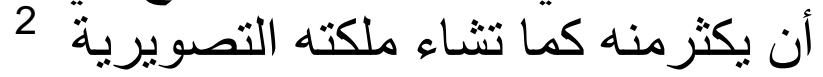

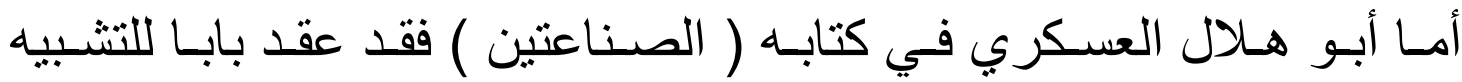

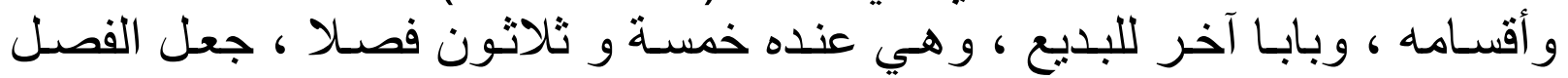

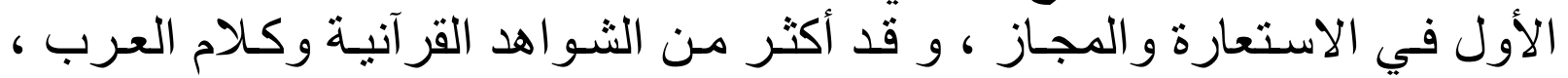

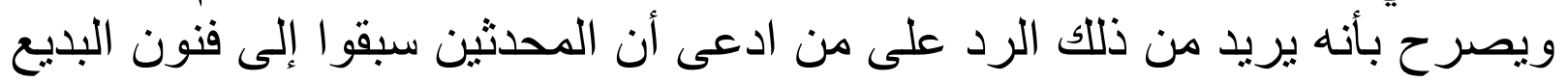

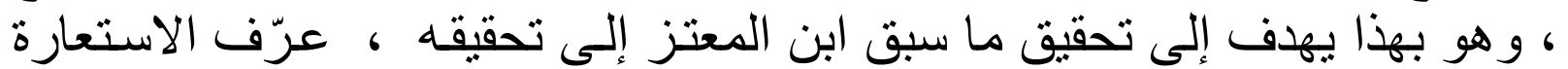

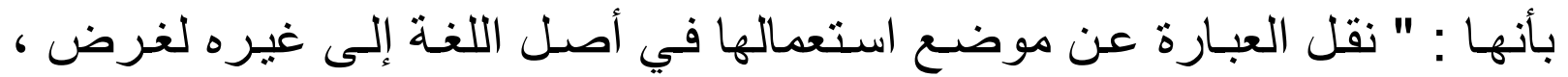

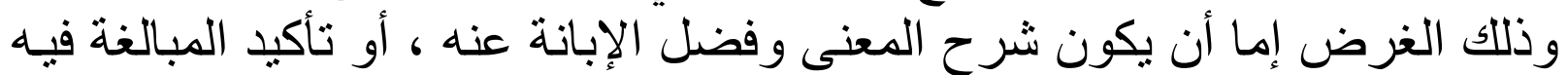

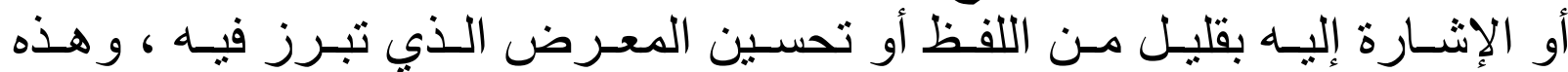

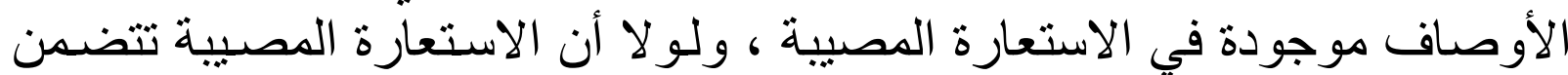

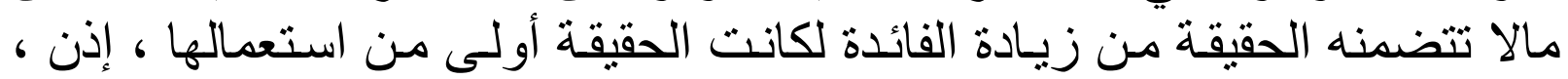

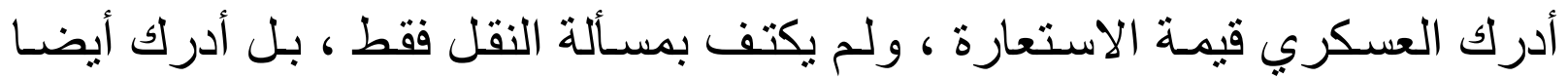

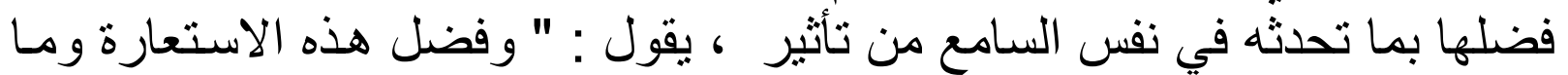

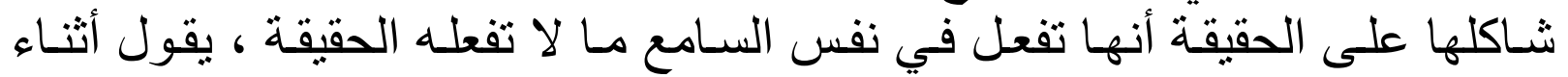

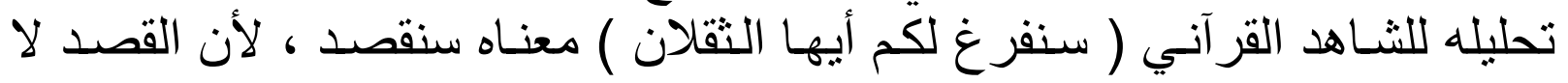

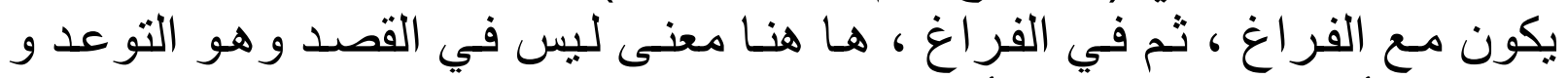

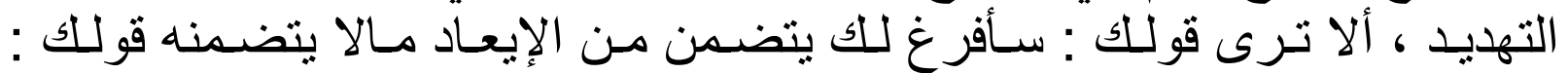

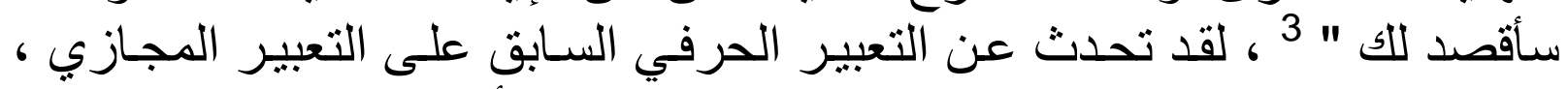

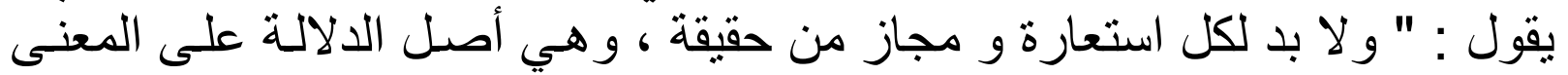
وقد أغتدي والطيـر في وكناتهـا بمنجرد قيـد الاو ابـد في اللغة ، كقول امرئ القيس : لأدون هيكل

1 / المو ازنة بين شعر أبي تمام و البحتري ، لأبي القاسم الحسن بن بشر الآمدي ، تحقيق السيد أحمد صقر ، مكتبة الخانجي ،

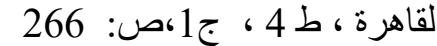

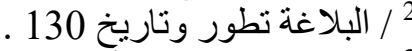
3 / كتاب الصناعتين، لأبي هلال الحسن بن عبدالله العسكري ،المكتبة العصرية ،بيروت ، 1419 هـ ، ص : 268 . 


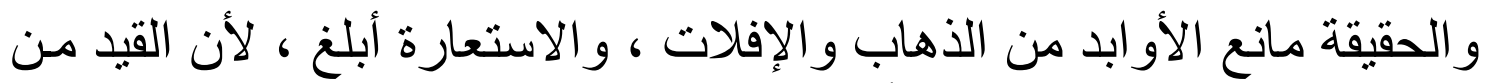

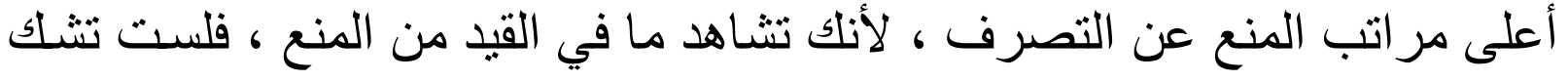
فيه " اعل عر

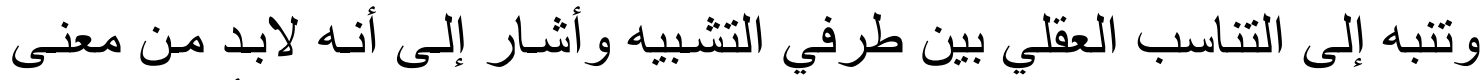

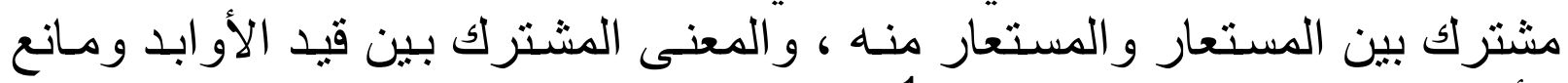

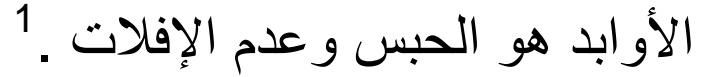

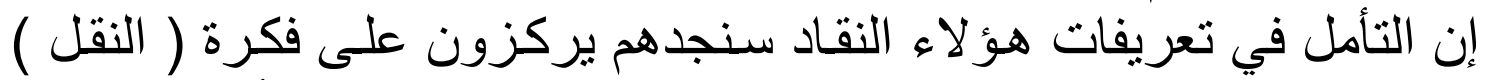

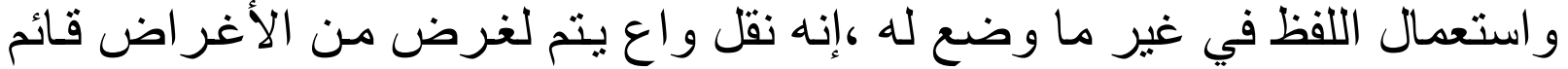

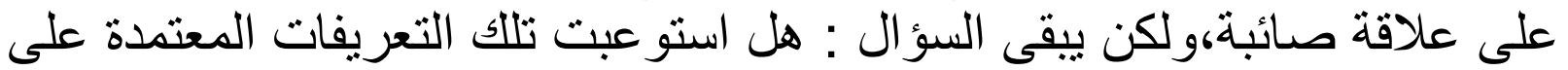

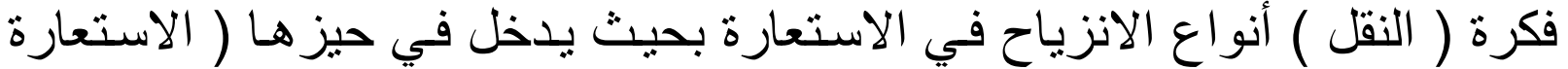

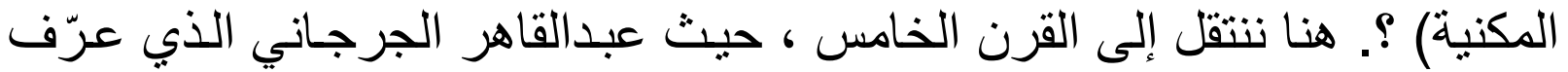

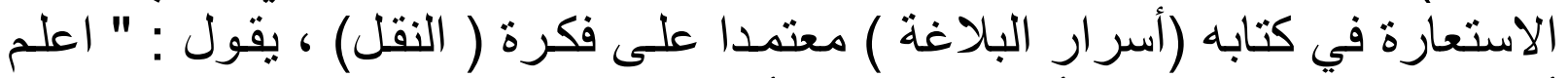

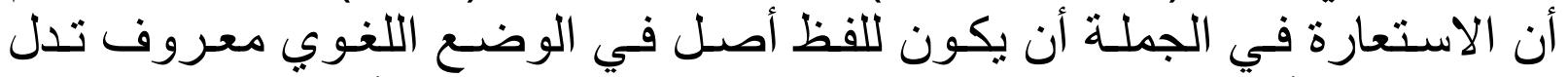

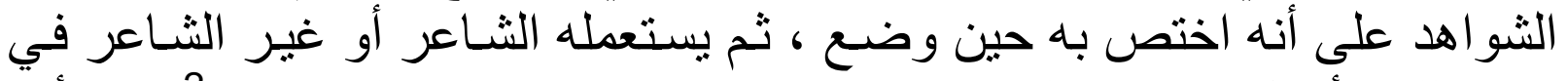

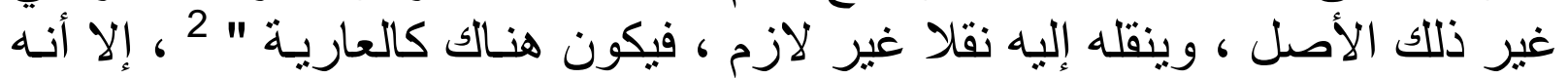

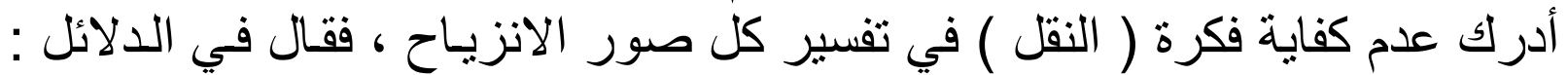

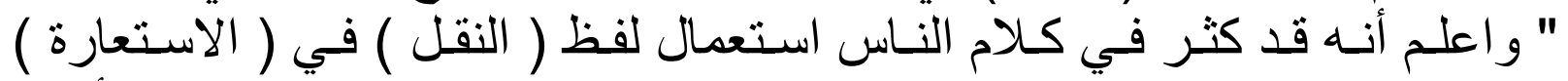

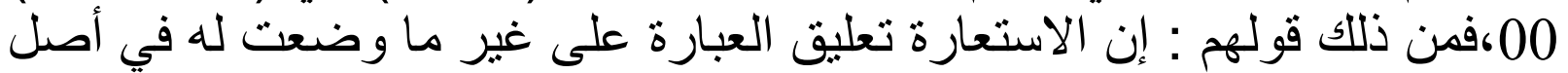

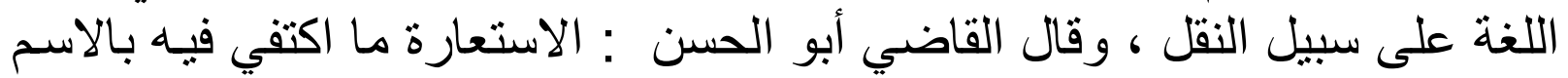

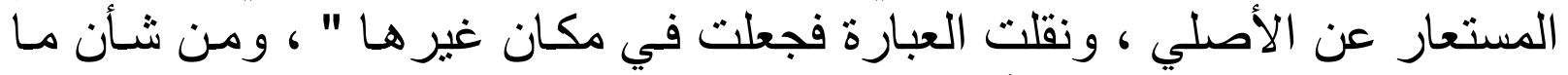

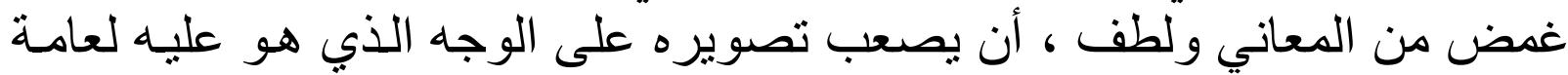

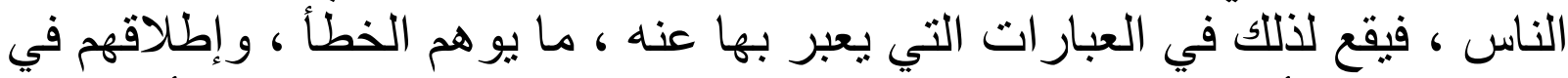

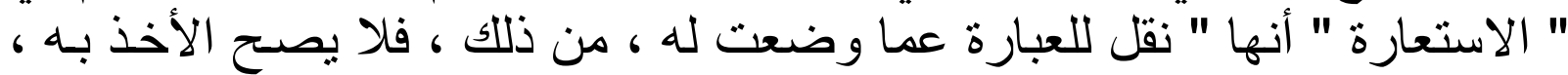

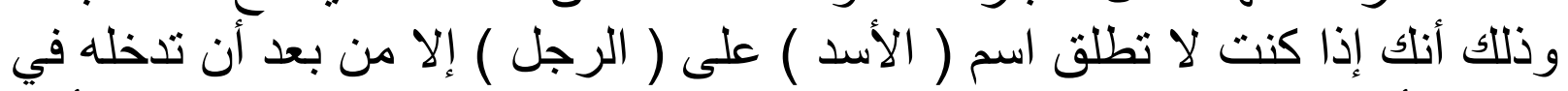

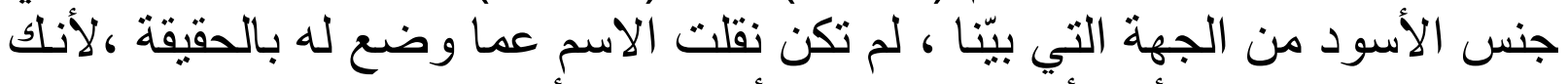

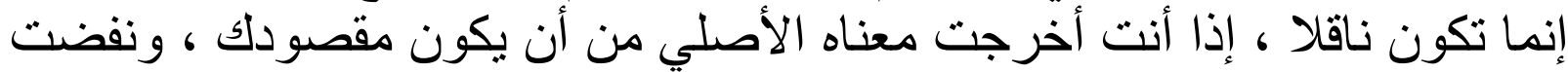

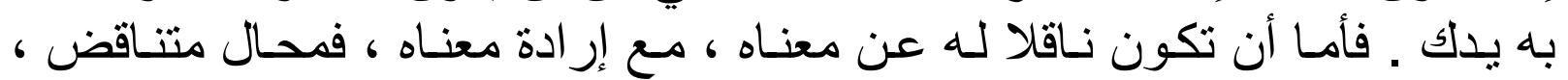

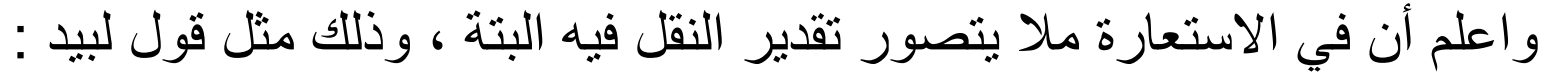

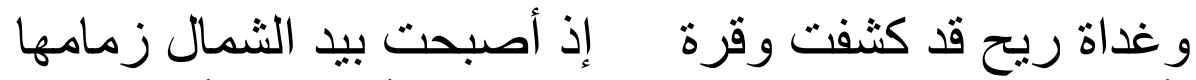

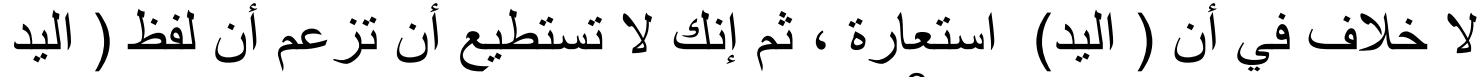

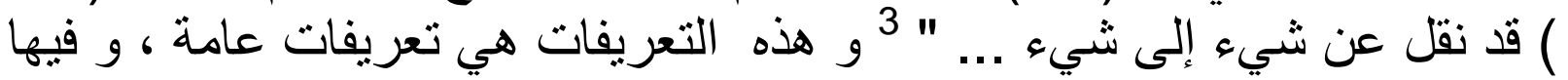




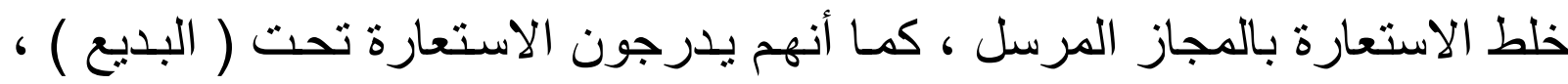

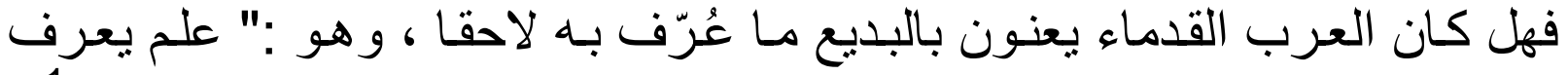

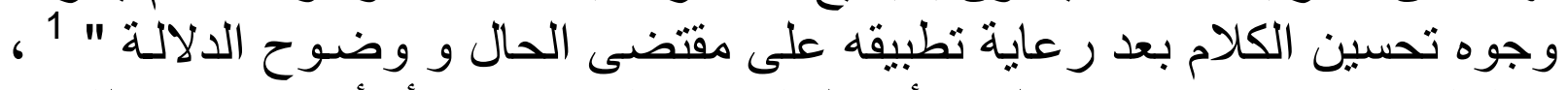

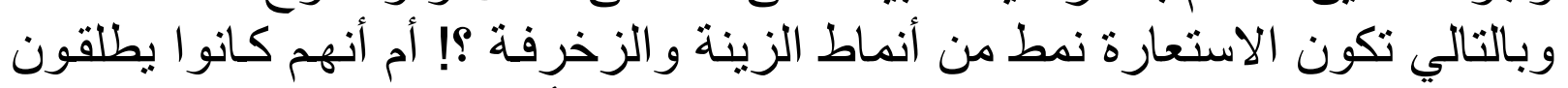

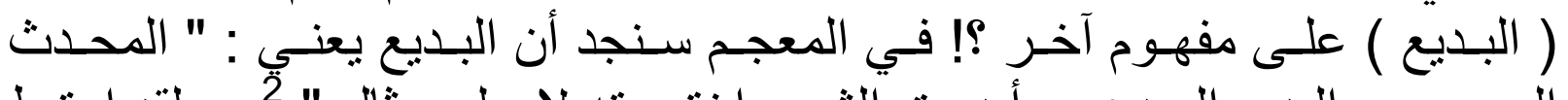

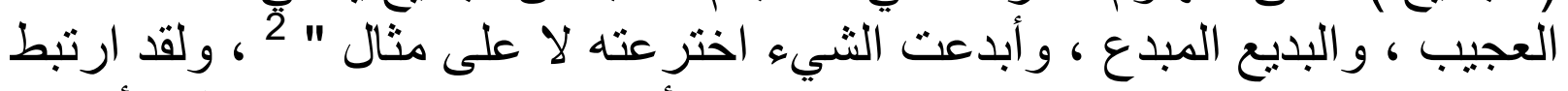

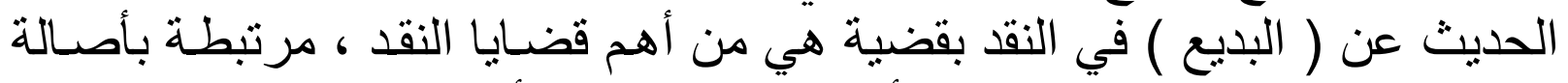

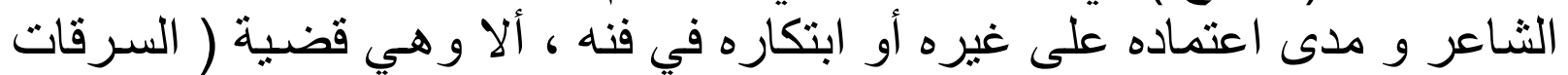

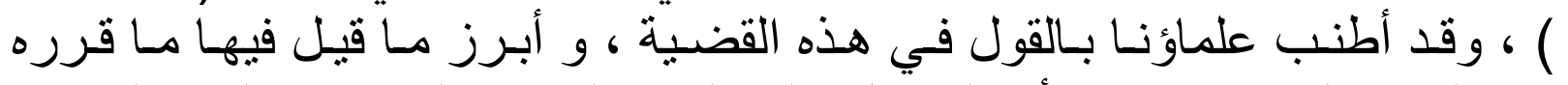

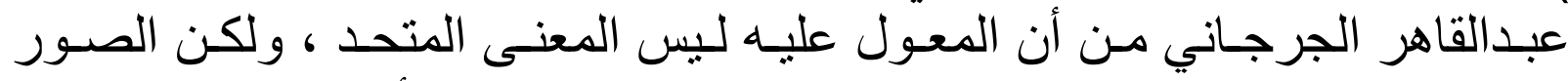

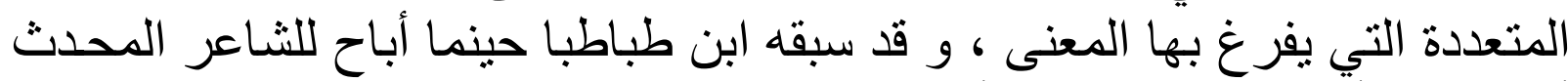

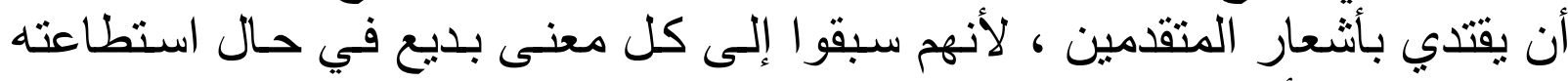

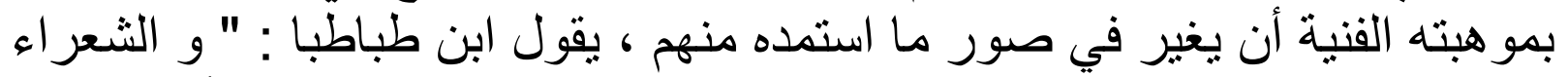

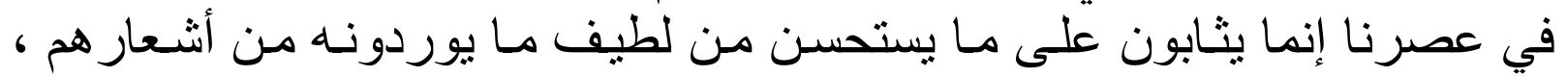

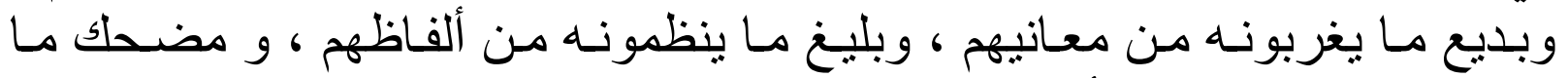

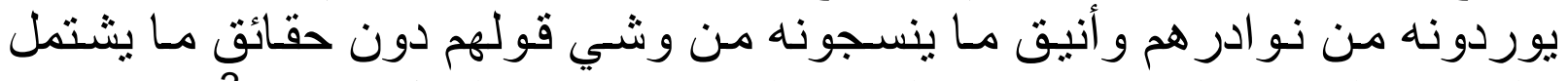

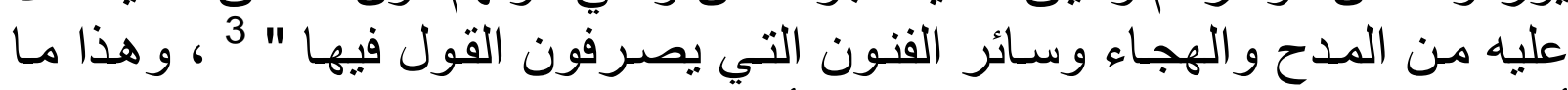

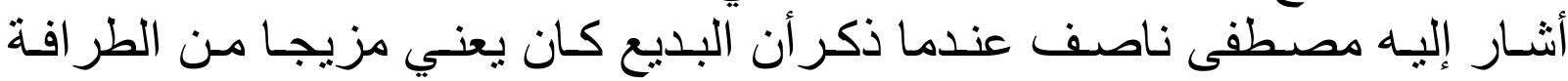

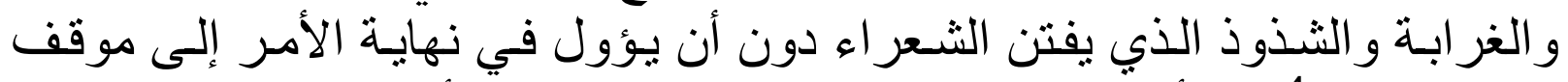

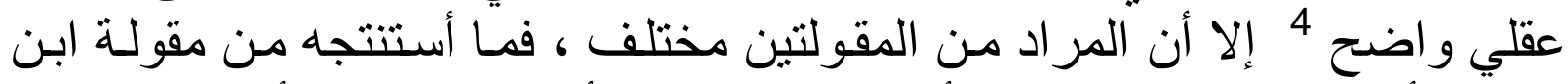

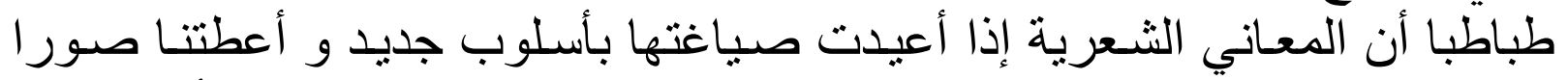

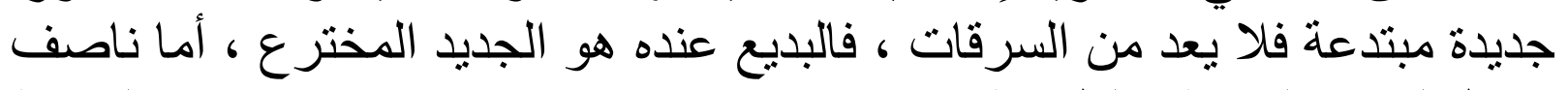

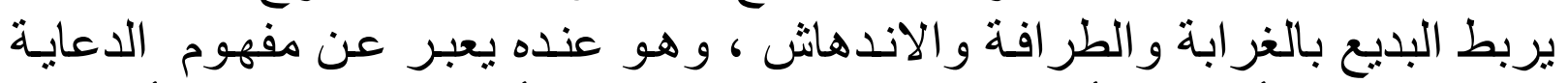

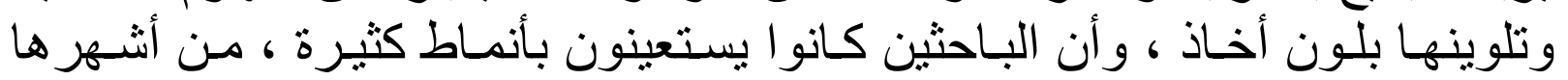

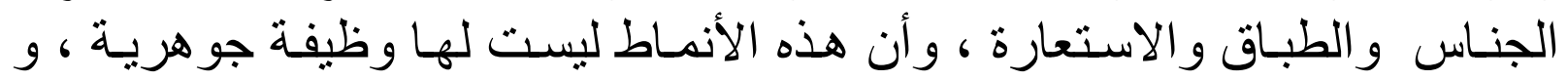

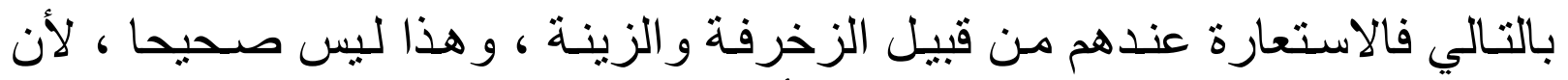

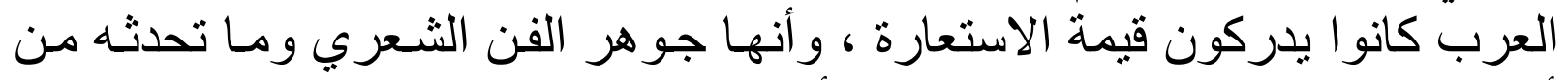

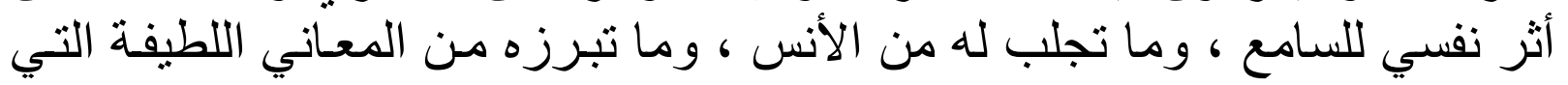

19 / كتاب الصناعتين ، لأبي هلال العسكري ، تحقيق علي محمالبجادي ، مححد أبو الفضل إبراهيم ، الدكتبة العصرية ،بيروت ، 2 / لسان العرب ، لابن منظور ، تحقيق أمين عبدالو هاب و محمد صادق العبيدي ، دار إحياء النراث ، بيروت ، ط3 ، 
هي من خبايا العقل كأنها قد جسمت حتى رأتها العيون 1 ، " إلا أن تفريع علوم إنهاء

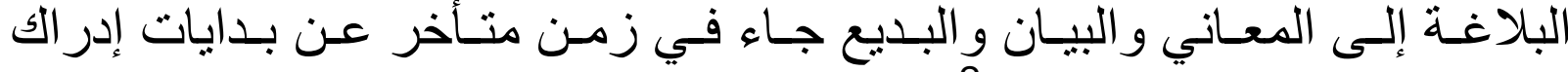

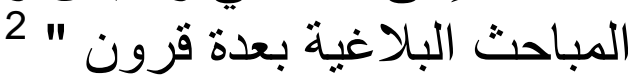

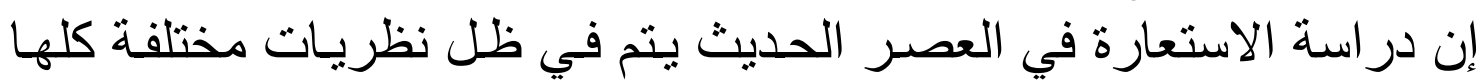

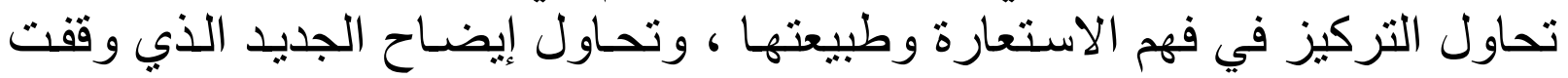

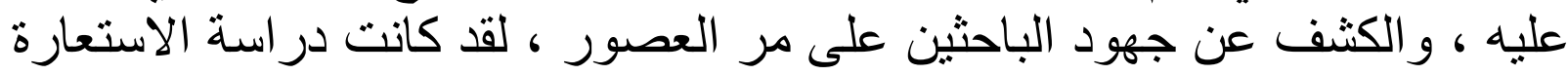

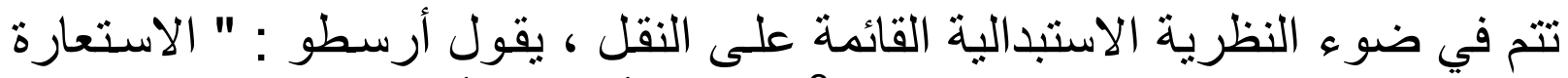

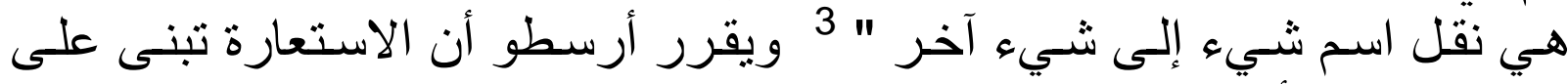

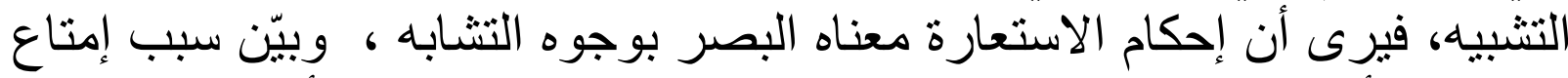

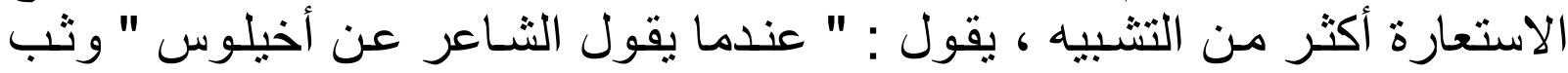

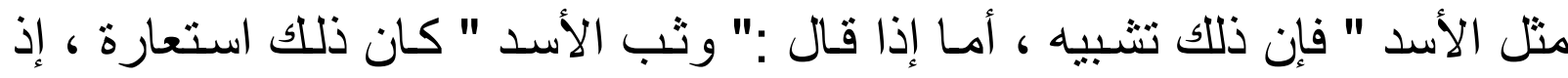

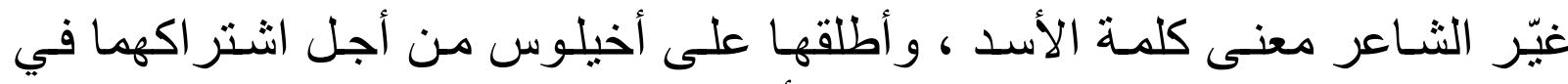

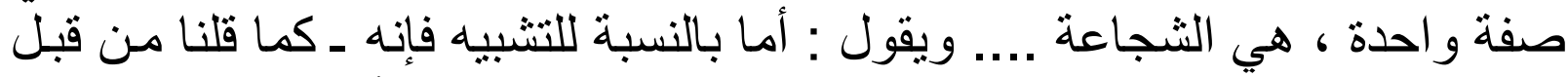

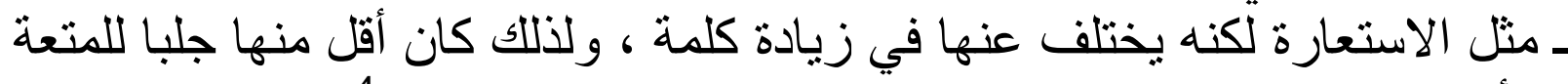

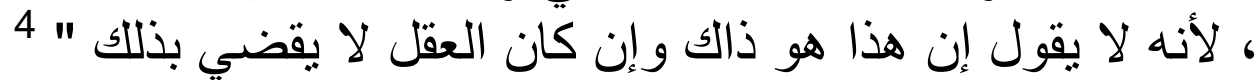

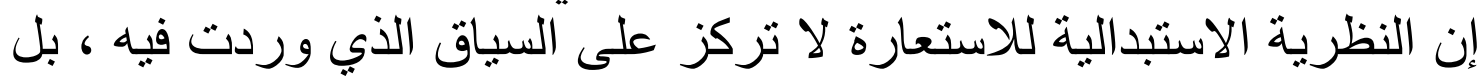

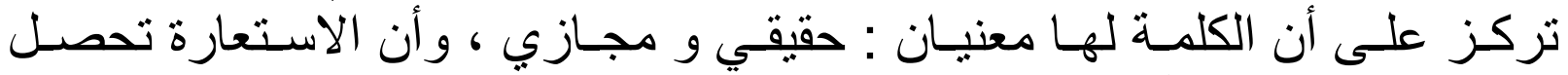

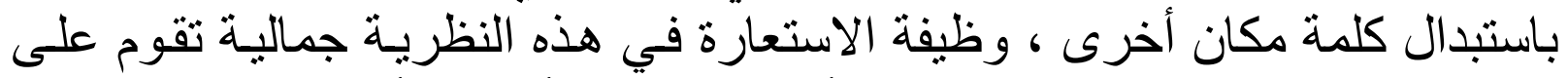

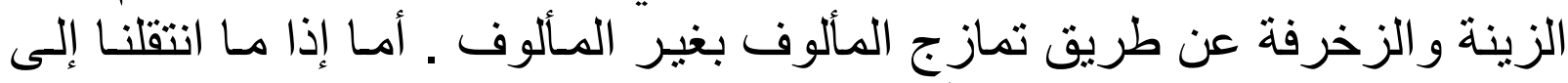

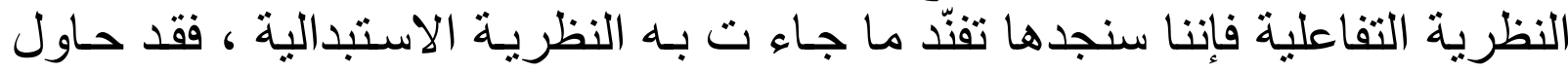

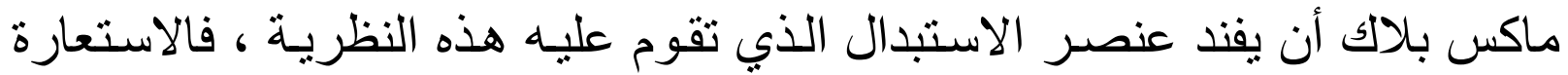

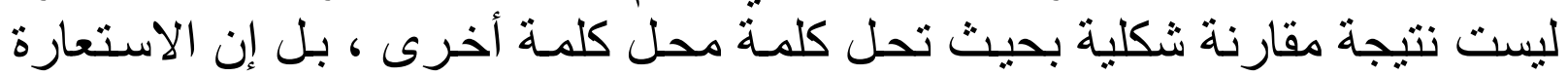

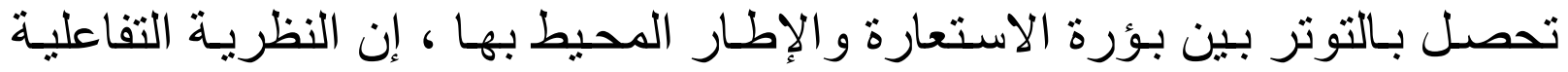

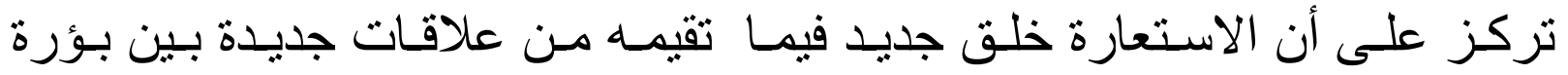

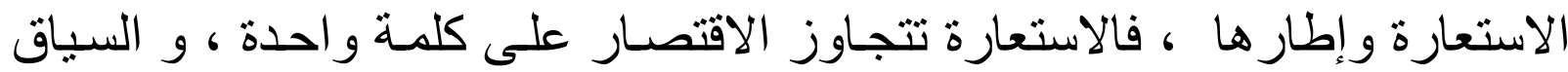

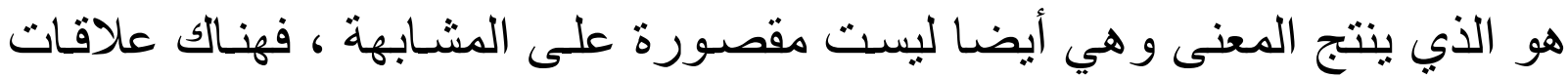

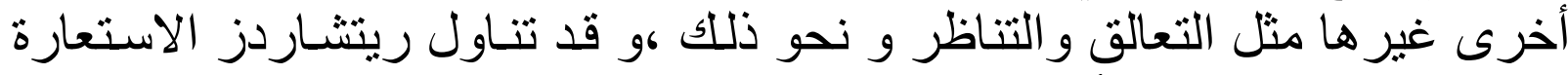

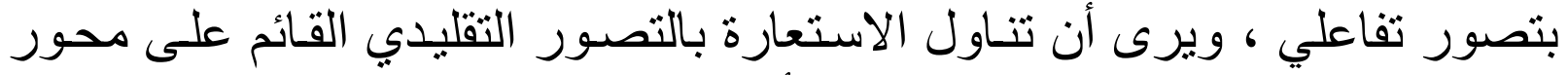

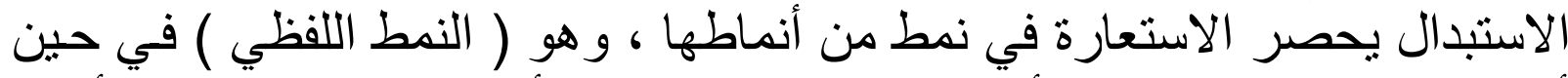

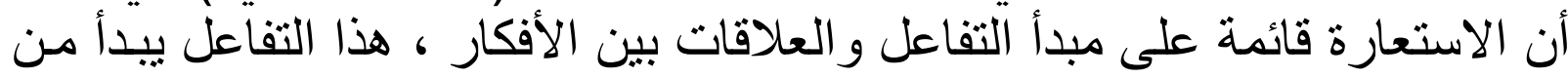

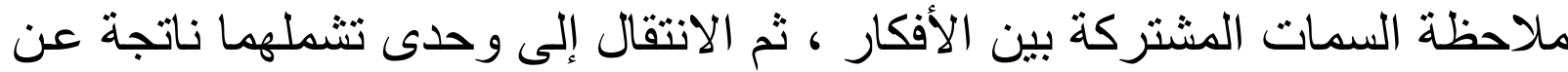


هذا التفاعل ، وهذه الوحدة الناتجة عن هذا التفاعل هي مولدة جديدة بو اسطتها

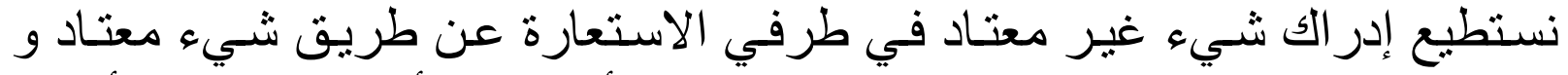

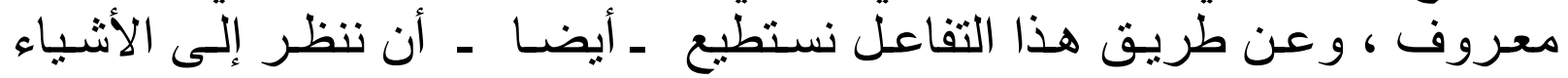

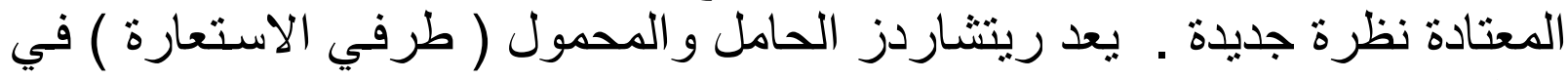

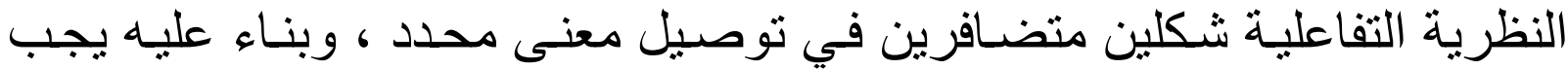

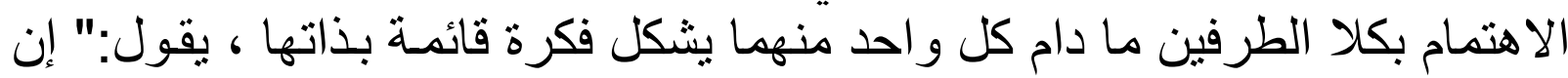

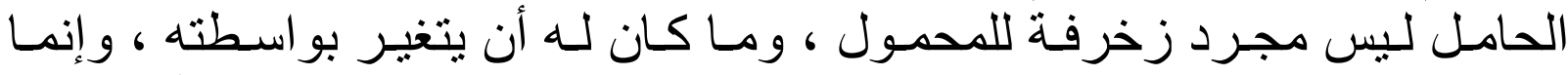

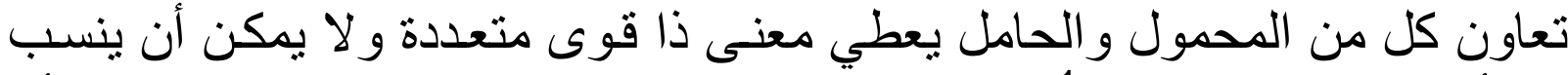

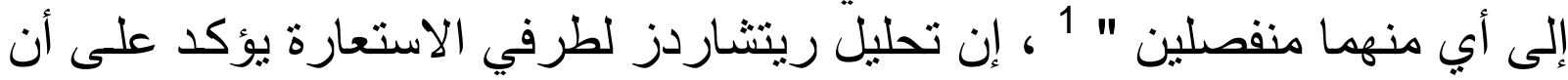
العلاقة بين الطرفين ليست منحصرة في علاقة ( المشـابهة ) إن مفهوم الاستعارة

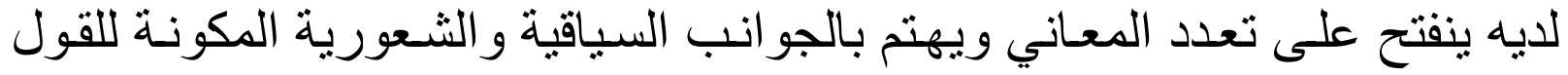

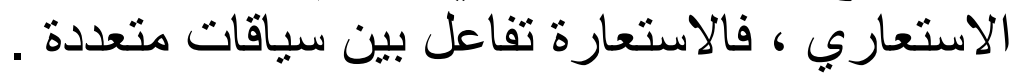

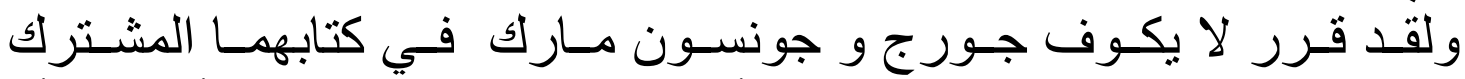

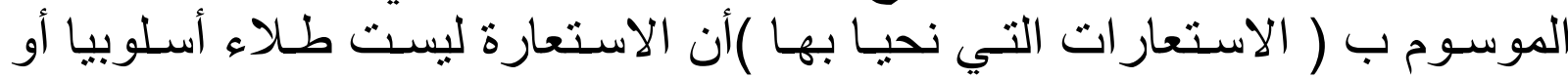

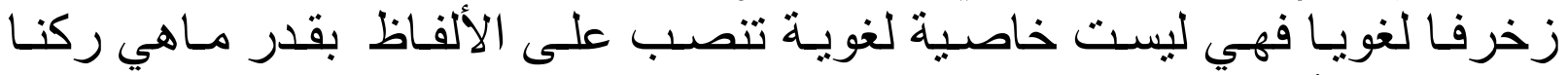

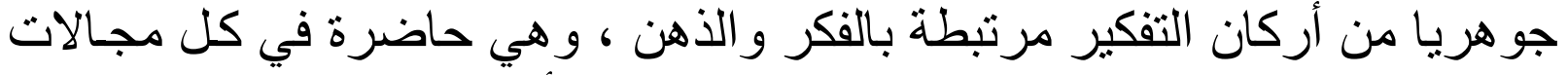

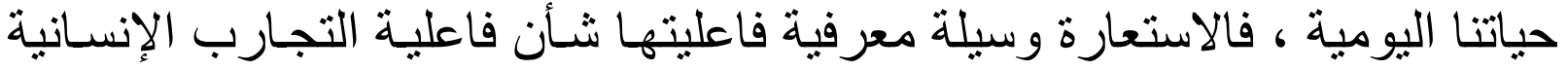

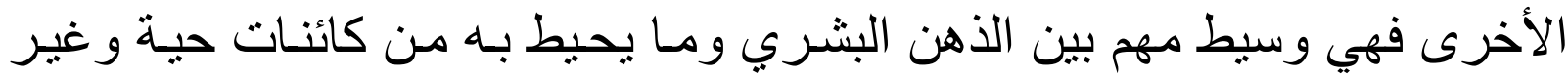

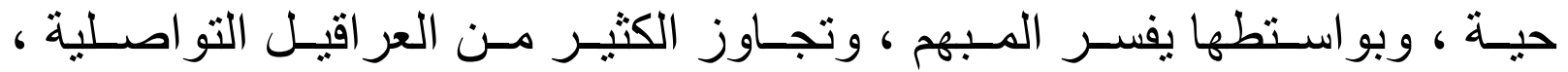

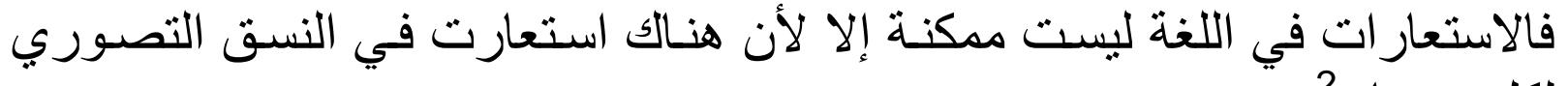

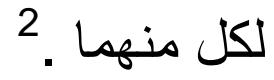
خاتمة: منها

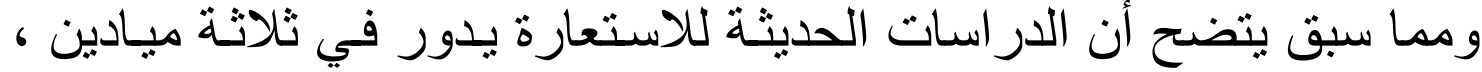

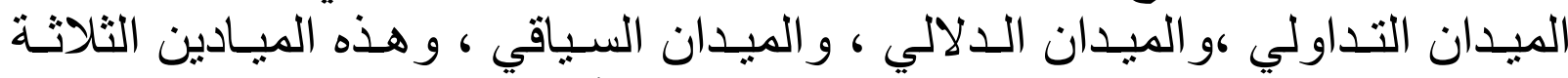

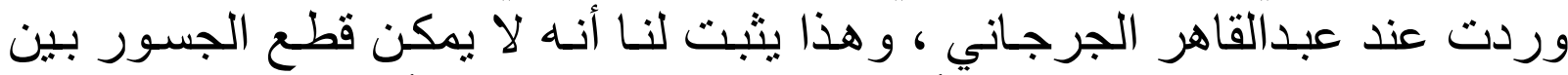

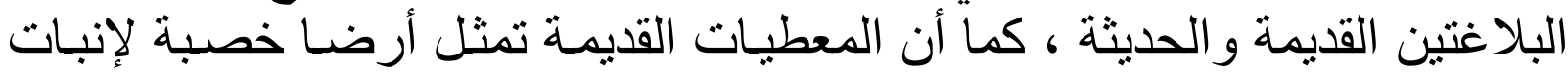

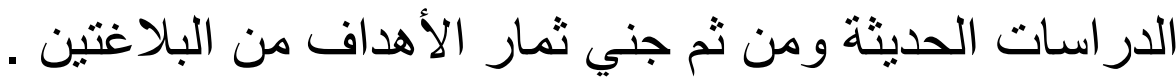


مجلة كلية الآداب بالو ادي الجديد، العدد الثالث 


\section{ثبت المصادر والمراجع}

1/ الأدب المقارن ، د. غنيمي هلال ، نهضة مصر ،.1997

2/ الاستعار ات التي نحيا بها ، جورج لايكوف ومارك جونسون ،ترجمة عبد

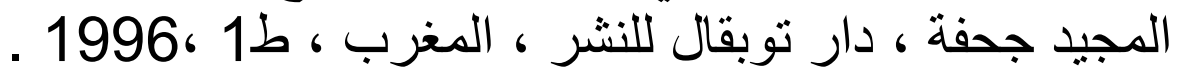

الاستعارة في محطات يونانية و عربية وغربية 173 ـ

14 أسرار البلاغة، عبد القاهر الجرجاني ،تحقيق محمود شاكر ،دار المدني ،

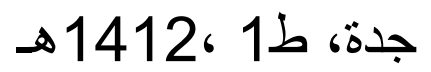

5/أصول النقد الأدبي، أحمد الثايب، مكتبة النهضة المصرية ،ط 10 ، 2002

6/البديع لأبي العباس عبداله بن المعتز ،تحقيق عرفان مطرجي ،ط1،

7/ البلاغة تطور وتاريخ ، ـد.شوقي ضيف ،دار المعارف ط ،1992.

8 / البلاغة،مدخل لدراسة الصور البيانية ، فر انسوا موروا، ترجمة محم الولي،

أفريقيا الثرق، 2003 البدة

9/ بنية الصورة الثعرية عند أبي تمام، هبة غيطي، إثراف الدكتور الربعي بن فن فين سلامة(رسالة ماجستير)،جامعة منتوري، قسنطينة.

10/ البيان والتبين،لأبي عثمان عمرو بن بحر الجاحظ ، تحقيق عبد السلام

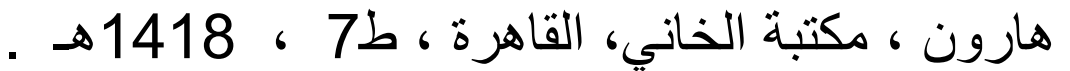

11/ تأويل مشكل القران،لأبي حمحدعبداله بن مسلم بن قتبية ، تحقيق إبراهيم

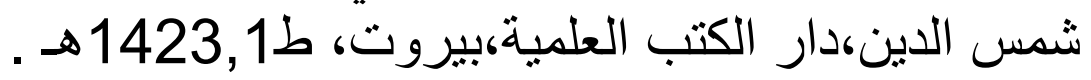

12/ الحيوان ،لأبي عثمان بن عمروبن بحر الجاحظ ،دار الكتب العلمية

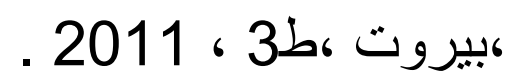
13/ الخطابة ،أرسطو، تحقيق: عبدالقاهرقنيني ، أفريقيا الثرق. 
14/ دراسات في النقد المعاصر ، د.زكي عشماوي، دار المعرفة الجامعية ،

.2000

15 / دلائل الإعجاز،عبد القاهر الجرجاني ،تحقيق : محمود شاكر، مكتبة

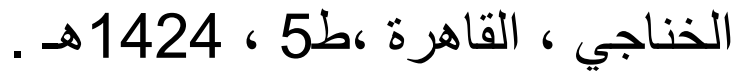

16/ السرقات الثعرية ، د.مصطفى هدارة ،المكتب الإسلامي ، ط 3 1401،

$$
\text { 17/ الصورة الأدبية ، د. ناصف ، دار الأندلس ، بيروت . }
$$

18/18، الصورة الثعرية ، أحمد مطلوب ،مجلة المجتمع العلمي ،ج1 ،مجلد 46

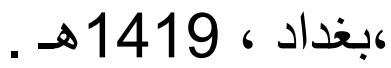

19/ الصورة الفنية في التراث النقدي والبلاغي ، جابر عصفور، دارالكتاب المصري ،ط1 ، 1424 هـ .

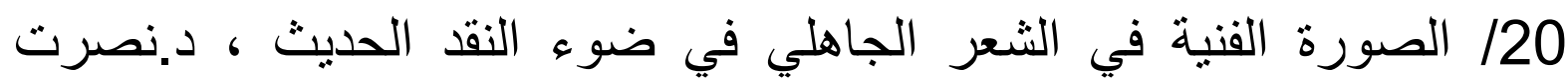

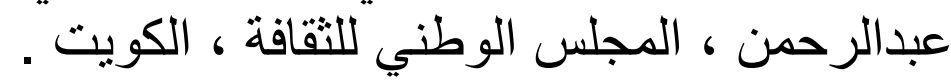

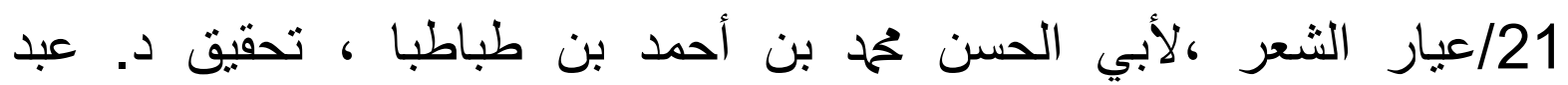

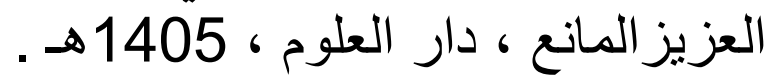

22/ فلسفة البلاغة ،ايفور ريتشاردز ، ترجمة : سعيدالغانمي ،أفريقيا الثرق ،

.2002

23/في الثعر ،تحقيق : شكري عياد ، المركز القومي للترجمة ، القاهرة ،

.2012

24/ لسان العرب ، لابن منظور ، تحقيق أمين عبد الوهاب ورحمد صادق العبيدي

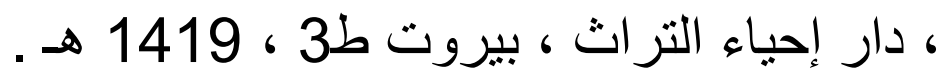

25/ محاضر ات في علم البيان ، د ـ ـ عيد علي بلبع مكتبة الرشد، الرياض ،ط1 . 1429 ،

26/مفهوم الاستعارة ، د.أحمد الصاوي منشأة المعارف ، الإسكندرية ،1988 ـ 
278/ مقدمة لدر اسة الصورة الفنية ، دـ. نعيم اليافي ، منشورات وزارة الثقافة ، دمشت 1982.

28 منهاج البلغاء وسراج الأدباء حازم القرطاجني ، تحقيق حمد الحبيب بن خوجة ،دار الغرب الإسلامي .

29/ الموزنة بين شعر أبي تمام والبحتري ، لأبي القاسم الحسن بن بشر الأمدي

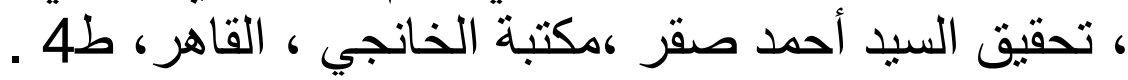

130 نحو مذهب اسلامي في الأدب والنقد ، د. د. رأفت الباثـا ،دارالأدب الاسلامي، ط4 ، ندو مد 1418 هـ .

31/ النقد الأدبي الحديث د. غنيمي هلال ، دار نهضة مصر للطباعة والنشر .

32/33/ النقد الأدبي الحديث ، حمح الثطي ، دار الأندلس للنشر والتوزيع ، 1419

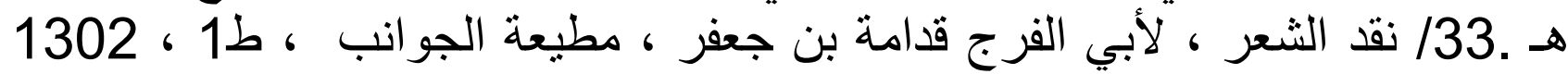

